\title{
LA FÁBULA DEL CABALLO Y EL ASNO EN EL LIBRO DEL ARCIPRESTE DE HITA
}

\author{
Margarita Morreale
}

La fábula del caballo y el asno, que en el Libro de Juan Ruiz (JR) ocupa los vv. 237-245, ha sido objeto de algunas intervenciones textuales y glosas léxicas, principalmente en la edición de $\mathrm{J}$. Corominas ${ }^{1}$; junto con las otras fábulas, de un estudio de las fuentes en el extenso ensayo de O. Tacke ${ }^{2}$; de una presentación histórico-literaria sucinta, pero más matizada, en el memorable libro de F. Lecoy ${ }^{3}$; de algunas observaciones en un ensayo de I. Michael sobre la función de las fábulas en el Libro, como narrativa "popular" ", dentro del temario articulado de la narrativa universal clasificada con este nombre ${ }^{5}$; de una apostilla arabizante de M. R. Lida de Malkiel ${ }^{6}$; sin men-

\footnotetext{
1 Madrid, BRH, 1967.

2 "Die Fabeln des Erzpriesters von Hita und ihre Stellung ihm Rahmen der mittelalterlichen Fabelliteratur", Romanische Forschungen, 31 (1911-1912), 598-705; para nuestra fábula, cf. las págs. 626-631.

3 Recherches sur le Libro de buen amor de Juan Ruiz, París, 1938, ed. facs. Hants, 1974, págs. 125-126.

4 "The Function of the Popular Tale in the Libro de buen amor", en Libro de buen amor Studies, ed. G. Gybbon-Monypenny, Londres, 1970, págs. 177-218.

$\checkmark$ S. Thompson, Motif-Index of Folk-Literature, Copenhague, 1955-58², L 452.2. "Cambio de fortuna: el orgullo humillado", A. Aarne y S. Thompson, The Types of the Folktale: A Classification and Bibliography. Helsinki, FF Communications n. 184, 1961, 214 * "cuentos de animales"; a cuya tipología, por lo demás, ya había remitido Perry en su edición de las fábulas de Babrio y Fedro, v. i. n. 21.

- Cf. "Nuevas notas para la interpretación del Libro de buen amor", Nucva Revista de Filología Hispánica, XIII (1959), 26. A propósito del v. 242c señala que en el Libro de las delicias de Yosef ben Meir Ibn Sabarra (cf. 1. ${ }^{a}$ ed. de I. González Llubera [Barcelona, 1931], pág. 57) se habla de "acémilas tan extenuadas que se arrodillaban como si tuviesen que rezar"; en su Selección del Libro de buen amor (Buenos Aires, 1941), la autora había incluido los versos que aquí nos interesan; cf. reimpr., ib., 1973, págs. 52-53.
} 
cionar las observaciones de parte de los estudiosos del Libro en su conjunto, de algún aspecto del mismo, o de su estructura narrativa ${ }^{7}$. Para los antecedentes tenemos además la magna obra de F. Rodríguez Adrados, que acaba de dedicar una especial atención a la fábula que aqui nos interesa ${ }^{8}$.

Las bien documentadas notas léxicas de J. Corominas (Cor.), y también la discrepancia para con su transformación de la estr. 242, nos encaminan hacia el estudio morfosintáctico, léxico y estilístico del texto.

Las fronteras entre los distintos métodos que aqui se prospectan no son $\tan$ netas como podrian parecer. Por un lado, el propio Lecoy, el máximo representante del estudio de las fuentes escritas, afirma que JR tendría un conocimiento tradicional "difuso" de las fábulas esópicas". Por otro, I. Michael, tras colocar el cuento ruiciano del caballo y el asno en la casilla que le corresponde en la tradición fabulistica, lo trata, brevemente, como un texto literario ${ }^{10}$.

En efecto, si bien las fábulas llevan intrínseco el propósito de ser narradas, y por tanto la comunicación oral (que a su vez produjo la condensación en la forma del proverbio; del Libro se cita el dicho 929c "la liebre del covil saci la comadreja", alusivo a la fábula del gato, la comadreja y el conejo), la transmisión conocida es de tipo monástico o escolar, con elaboraciones literarias y retóricas, que se sobreponen al texto aprendido de memoria.

Es esencial conocer tanto la fábula latina en prosa que el Arcipreste había "decorado" en sus días escolares, como el texto literario que escogió como reto a su arte de metrificar. Esto, para el establecimiento del texto, como testimonio adicional al de los manuscritos, y a veces más decisivo, y como término de comparación para aquilatar el arte del autor castellano como traductor y como narrador.

Haremos hincapié en el estudio sincrónico del texto castellano en el plano de la letra, encasillando los distintos aspectos de manera que se puedan comparar con los modelos, tras determinar en lo factible las opciones que se le ofrecían ${ }^{11}$; pero no sin antes presentar la fábula en su conjunto.

7 Cf. V. Marmo, Dalle fonti alle forme. Studi sul Lba, Nápoles, Romanica Neapolitana, 1983, pág. 137 et passim.

8 Historia de la Fábula greco-latina, Madrid, Universidad Complutense, 1979-1987, 3 vols. ; del mismo, "Aportaciones al estudio de las fuentes de las fábulas del Arcipreste", en Philologica Hispanicusia in honorem Manucl .4litur 3 Litcrutura, Madrid, BRH. 1987, 459-473, al que nos referimos como Rz. Adrados².

- I.oc. cit., pág. 120.

10 Loc. cit., pág. 194

11 Fuera del ámbito esópico hemos recorrido el mismo laborioso camino para el “Ave María glosada" (1.661-1.667) y para los "Gozos de la Virgen" (20-43, 1.635-1.648), respectivamente en Bolctín de la Biblioteca dc Menindez Pelayo, 57 (1981), 5-44, y Revista de Filologia Española, 63 (1983), 223-290, y 64 (1984). De entre las fábulas hemos estudiado hasta ahora la del alano que llevaha carne en la boca (226-229), la del 
Este es el texto con su aparato, incluida la estrofa que precede inmediatamente, transcrito del códice salmantino (S), que es el único que lo contiene, con un minimo de unificación de la grafía y con las enmiendas necesarias.

236 El omne muy sobervio e el muy denodado, que non ha de Dios miedo nin cata aguisado, ante muere que otro, más flaco e más lazrado; contece 1 como al asno con el cavallo armado.

Ensiemplo del cavallo e del asno.

237 Iva lidiar en campo el cavallo faziente porque forçó la dueña el su señor valiente; lorigas bien levadas, muy valiente se siente; mucho delante liva el asno maldoliente.

238 Con los pies e las manos e con el noble freno, el cavallo sobervio fazía tan grand sueno, que a las otras bestias espanta como trueno: el asno con el miedo quedó, e no.l fue bueno.

239 Estava refusando el asno con la carga ; andava mal e poco, al cavallo embarga. Derribó-1 el cavallo en medio de la varga ; diz: "Don villano necio, buscad carrera larga."

240 Dio salto en el campo, ligero, apercebido; coidó ser vencedor e fíncó el vencido; en el cuerpo, muy fuerte de lança fue ferido: las entrañas le salen; estava muy perdido.

241 Desque salió del campo, non valié una cermeña; a arar lo pusieron e a traer la leña, a vezes a la noria, a vezes a la acenia ; escota el sobervio el amor de la dueña.

242 Tenié con el grand yugo essolladas las cervizes, del inojar a vezes finchadas las narizes, rodillas dessolladas, faziendo muchas prizes, ojos fondos, bermejos como pies de perdizes;

243 los quadriles salidos, somidas las ijadas, el espinazo agudo, las orejas colgadas. Vidolo el asno necio, rixo bien tres vegadas.

Diz: - Compañón sobervio, ¿đó son tus empelladas?;

lobo y la grulla (252-256), la del asno y del blanchete (1.401-1.411), la de la raposa y el cuervo (1.437-1.444), la de las liebres (1.445-1.453) y partes de las otras, pero sin entrar en los antecedentes latinos con tanto detalle textual (aun asi insuficiente) como lo hacemos en ésta, la primera que hemos examinado punto por punto. Anteriormente habíamos publicado una nota sobre la fábula "del gallo que falló un çafir en el muladar (1.387-1.391)", en Studia hispanica in honorem R. Lapesa, Madrid, 1975, págs. 369-374. 
$2+4$ ¿dó es tu noble freno e tu dorada silla?; ¿dó es la tu sobervia?; ¿dó es la tu renzilla? Siempre bivrás mesquino e con mucha manzilla; vengue la tu sobervia tanta mala postilla."

245 Aquí tomen ensiemplo e lición cada dia los que son muy sobervios con su grand orgullia; que fuerça e edad e onra, salud e valentía non pueden durar siempre, vanse con mancebía.

236a el (2) - : 238a las manos praem. con : 239a carga praem. grand; 239b enbargava : 239c derribole: 241a valya; $242 \mathrm{a}$ tenia / con el : del / dessolladas: $243 \mathrm{~d}$ compañero; $244 \mathrm{~b}$ la (1) -; $245 \mathrm{a}$ cada dia praem. de.

0. Otro cometido previo será el de presentar la fábula en su marco y resumirlo cual se nos presenta en sí, independientemente de toda consideración de fuentes. Pero no sin antes recordar que la fábula llamada "esópica" nació como obra de escritores individuales, y solo en un segundo momento fue recopilada en colecciones: que nació en verso, y pasó repetidamente por la conversión del verso a la prosa, y de la prosa al verso.

Por su estructura sencilla, encaminada a un desenlace aplicable a la condición humana, se prestó para la adaptación a varios mensajes. No sin motivo habían contribuido a su desarrollo los oradores callejeros de la antigüelad, los cínicos. Fue utilizada también en la predicación medieval; para este fin incluye 29 de ellas Vicente de Beauvais O. P. en sus magnas obras Speculum doctrinale y Speculum naturale. Célebre predicador fue Eudes u Odo de Cheritón, autor de Fabulae o Narrationes, algunas de las cuales aparecen adaptadas al español en el Libro de los Gatos.

En las lenguas vulgares el género de los apólogos de animales trascendió no sólo a los escritos más explícitamente didácticos, como el que acabamos de nombrar, sino a una abundante floración de obras de tono más recreativo, que hoy conocemos como literarias ${ }^{12}$.

0.1. En el Libro del Arcipreste la fábula que aquí nos interesa va enclavada en la increpación a Don Amor, donde ilustra la soberbia, uno de los ocho pecados capitales, que el autor-protagonista le imputa a su contricante en forma de sermón, recordando la caícla de Lucifer (cf. Apoc. 12:9). Con 1o que la parte que respecto a la fábula sirve de "marco" (230-235), pertenece

12 Véanse, entre otros, E. Winkler, “Das Kunstproblem der Tierdichtung, besonders der Tierfabel", en IIauptfragen der Romanistik. Festschrift fïr P. A. Becker, Heidelberg, 1922, y H. R. Jauss, Untersuchungen zur mittelalterlichen Tierdichtung, Tübingen, 1959. 
a la unidad temática inmediatamente superior, en ese engaste de una secuencia dentro de otra que muy bien ha ilustrado Marmo.

En la estrofa introductiva (236) se pone como destinatario de la fábula al soberbio empedernido, que en su obstinación no teme a Dios (no ha de extrañar b miedo de Dios por cuanto no se había fijado aún temor de Dios como sintagma), que no observa (ib. cata), lo que va acorde con la ley divina y con la de los hombres (ib. aguisado), y muere antes que otro más débil (flaco) y más desvalido (lazrado).

El último verso sirve de transición e introduce a modo de epígrafe el suceso que se va a narrar: "contecel (al soberbio enamorado) como al asno con el caballo armado" (a cuyo propósito holgará recordar que el verbo contecer, como ya su homólogo latino contingere, es propio del exordio de las fábulas, y significativamente también de las aventuras del propio poeta-protagonista cuando se ilustran con apólogos; cf. 174ab "Ansi conteció a mí con la dueña de prestar / como conteció al ladrón que entrava a furtar”; v. q. 225d).

0.1.1. En la mención progresiva le los personajes, sin embargo, el v. 236a, que acabamos de citar, revela cierta incongruencia, por cuanto hace suponer que el asno, mencionado en primer término, será la víctima, para escarmiento de los enamorados que, como se habia dicho arriba, 232b "mueren de malas muertes".

En una formulación tan poco exacta pudo influir el metro (v. i. B 4) o cierto apresuramiento impresionista, dentro del carácter imprevisible del dictado de JR: el asno es el primero a quien "contece" una desventura, al ser lanzado a la varga; además, desempeña el papel de protagonista en un buen número de fábulas esópicas (v. ๆ. i. IB 4).

0.1.2. La moraleja, colocada al final como remate del discurso conclusivo de uno de los personajes, es aplicada expresamente a los soberbios. En esto la fábula se diferencia de las sucesivas, clonde entre el cuento y la moraleja se intercala una cuarteta dirigida a Don Amor (cf. 255, 273, 289).

0.2.1. Los protagonistas, entrelazados por la acción y por sendas alocuciones, más que por un diálogo propiamente dicho, son los dos que hemos nombrado. Hay otros personajes más a quienes se alude, ya explícitamente: 237b el caballero y una dama, ocasión del combate; ya implicitamente: el contrincante de aquél, representado por su lan\%a (240c), y el amo o amos que mandan en el caballo cuando pasa a cumplir tareas serviles en el campo (v. 241b). 
0.2.2. El tiempo, indefinido, pero posterior al hecho que habia ofrecido el motivo de la acción (237b "porque forçó la dueña"), tiene su eje en la conj. temporal 241a desque, que lo divide en un "antes" y un "después", y se abre en la segunda parte hacia una secuencia de turnos de trabajo repetidos a diario (241c), y hacia la sujeción del caballo a un destino miserable, anunciado por las palabras del burro: 244c "siempre bivrás mesquino".

0.2.3. En la primera parte, los hitos de la narración los constituyen acontecimientos puntuales: el encuentro entre los dos personajes, descrito inclirectamente (239b) y preparado de manera impresionista por la parada del asno (238d) y por su dificultad de seguir adelante (239a); la entrada del caballo en el campo de la lidia y su salida de él (240a, 241a), descritas en sus efectos, pero no separadas entre si, ni de lo que sigue, por indicación temporal alguna. Quedan para la imaginación del lector el (violento) combate y la (¿ repentina?) derrota.

En la otra parte, el único hito puntual, separado de lo que precede por los aludidos turnos de trabajo y por la progresiva demacración del caballo, lo marca el segundo encuentro, que el lector infiere de un verbo escueto en pretérito indefinido, 243c "vídolo", y que se le ofrece en forma de discurso directo (243d "diz"), cuando el asno se dirige al que antes le había despreciado. El ver y el hablar van separados por tres carcajadas (243c).

Las preguntas retrospectivas finales contraponen el presente duradero a un pasado fugaz, enlazado temporalmente por signos efímeros.

0.2.4. El espacio es asimismo indefinido y abierto, marcado en el proscenio por la ubicación relativa de los dos animales, de los que se afirma que uno va $237 d$ "delante" del otro (no sabemos si a mucha distancia; v. i. I D 6), y en profundidad por la presencia de otros cuadrúpedos (?) a los que el caballo espanta con su estruendo (238c).

0.2.5. En la primera parte, el lugar ad quem, asignado desde un principio al personaje principal, es el campo de combate hacia el que éste se dirige (no tan inmediatamente, según veremos), participando en el aliento del amo (237a); el destino primero (no intencional) del asno es una varga no mejor definida, en que le echara el corcel (239c), a empujones, según se deduce de la posterior alusión a las $243 \mathrm{~d}$ empelladas del caballo.

En la zona rural donde se desarrolla la segunda parte con la "penitencia" del caballo, entrevemos campos arados para la siembra (241b) y zonas de monte alto o bajo, de donde trae la leña (ib.). Los artilugios rústicos para la provisión y el aprovechamiento del agua (ib. c) constituyen los límites es- 
trechos de la esclavitud, contrapuesta implicitamente por el “¿Dó son?” de los vv. 243d-244b al espacio ilimitado, donde el caballo en sus buenos tiempos había retozado a sus anchas, sembrando el espanto entre los equinos o en todo el mundo animal.

El campo (amojonado) del combate, a modo de trampa, divide las dos partes de la narración.

0.2.6. En la primera parte, acción y descripción alternan entretejiéndose $(237 \mathrm{a} / \mathrm{c} / \mathrm{d})$, y fluyen una dentro de otra $(238 \mathrm{a}-\mathrm{c})$, a veces con antecedente inplícito: en $238 \mathrm{~d}$ el asno se para ("quedó"); luego, en $239 \mathrm{~b}$, se describen sus andares trabajosos o nulos. En la tercera estrofa, 239a "estava refusando", responde, a modo de nuevo exordio, al relieve que se le quiere dar a carga, por contraposición a las guarniciones de las que hacía alarde el caballo.

0.2.7. La narración es diegética, o sea, se hace por el discurso directo en 239d, con una increpación brevísima, en términos de la lengua familiar, que prepara, por contraste, la réplica clel asno (243d-244). En parte, ésta remite retrospectivamente a la acción del caballo, 243d las empelladas, que ya mencionamos (para 244b renzilla, v. i. 0.2.13), y describe a éste (cf. en 244a el freno, la silla): en parte, está vuelta hacia la evaluación moral (243d "compañón sobervio", 244b "la tu sobervia"), en términos que en boca del asno no están nada acordes con su "necedad".

0.2.8. El relator interviene con algunos comentarios: 238d "[quedó,] e no.1 fue bueno", 240d "estava muy perdido", y sobre todo, con la constatación $240 \mathrm{~b}$ "coidó ser vencedor e fincó el vencido", que se destaca por su tono sentencioso.

0.2.9. Fuertemente realzado en un principio, el "personaje" principal, a quien para sus buenos tiempos se asigna hasta una 244a silla de oro, o dorada, queda luego como absorbido, enfangado, en el escenario rústico de sus labores. El personaje secundario, descrito al principio con un rasgo negativo, como bestia de carga "maldoliente" por el peso, sale al proscenio en el v. 243c, pero sin perder, según vimos, su epiteto de "necio".

Entre la descripción del caballo en su gloria de 238a-c, que, como veremos, es ampliación de una sola palabra del modelo, y la del caballo vencido, en 241 (menos d)-243b, hay una proporción comparable con la que vimos entre la increpación y la réplica: de menos a más, por el peso relativo de los dos polos. 
Como manifestación exagerada de exuberancia y superioridad, la descripción de la estr. 2.38 prepara la invalidación, como en otras fábulas (p. ej., la de la raposa y del cuervo, 1.437-1.442). El estruendo vano (238c) acarrea la ruina como, en otia, las bramuras de la tierra (98a) conducen al nacimiento de 100 c "un mur topo".

La ironia se explaya también en el interior de las partes: en la exclamación del caballo, el título de $239 \mathrm{~d}$ "don villano necio" unido con el tratamiento de vós, se presta a que el asno le vuelva "la pelleja", llamando 243d compañón al caballo caido en desgracia.

Una especial atención merecen los vv. 242a-243b:

Tenia con el grand yugo essolladas las cervizes, del inojar a vezes finchadas las narizes, rodillas dessolladas, faziendo muchas prizes, ojos fondos, bermejos, como pies de perdizes;

los quadriles salidos, somidas las ijadas, el espinazo agudo, las orejas colgadas,

que, aun siendo amplificación del modelo latino, interesan como descripción del caballo demacrado y/o viejo, con las órbitas hundidas, los ojos rojos del mucho lagrimar, el esqueleto a flor de piel por haberse resecado los músculos de la espalda, las orejas gachas por no quedarle al animal fuerzas para levantarlas: toda una descripción canónica del caballo viejo o exhausto (como veremos), pero no sin suscitar alguna duda.

Para comodidad del lector incluimos también el texto de la estr. según quisiera reorganizarla Corominas (Cor.):

Tenia con el grand yugo folladas las cervizes del inojar a vezes faziendo muchas prizes, rodillas dessolladas, finchadas las narizes, ojos fondos, bermejos, como pies de perdizes.

Así "faziendo muchas prizes" viene a relacionarse directamente con "del inojar a vezes", del que "rodillas dessolladas" sería la consecuencia inmediata ; asi, "finchadas las narizes" podría desligarse como signo de la dilatación producida por el cansancio o por la edad. En el texto cual nos lo presenta el MS, en cambio, la hinchazón y el inojar vienen unidos con el tope del morro en el suelo, ¿ como alusión al rezo musulmán?, ¿ al cristiano? El arrodillarse es común a ambos (cf. Petrarca, ranción 29, "Perché inchinar a Dio molto convene / le ginochia e la mente"), y cierto grado de proskinesis también, pero más de aquél, especialmente si se toma a vezes como 'por turnos' (v. i. E 3.2). En sentido contrario a una identificación demasiado 
precisa obra la difusión de las metáforas de cuño religioso; en italiano las flexiones de la cabeza del caballo cansado o viejo se llaman incensare.

Por lo demás, el discurso no es tan homogéneo y fluido como podría parecer a primera vista: la 244b rcnzilla (v. q. i. I D 1.2) que el asno echa de menos en el caballo vencido, consuena mal con la despedida de éste, tras echar a rodar al burro que le estorbaba (239d); v. i. D 1.2.

En cuanto a la estructura del cuento, aparte del desdoblamiento: el asno se para (238d) y luego se describe su andadura lenta o nula (239b), la descripción hiperbólica del caballo en su gloria, y la otra realista de los efectos de las labores del campo sobre su físico, restan a esa concisión típica del cuento "esópico" que mueve rápiłlamente hacia el desenlace.

0.2.10. No podemos pedir demasiada cohesión a la fábula por cuanto obedece no sólo a la ilustración de la codicia, sino a la de la lujuria, connatural a Don Amor (cf. 231cd), en conexión con la secuencia temática en la que está incluida, y en consonancia con el papel doctrinal que el poetaprotagonista, por fas o por nefas, se adjudica. La lujuria pudo ser la causa de introducir el personaje humano (en la estr. 74, JR atribuye este vicio únicamente al hombre, entre todos los seres creados, aunque también se consideraba como propia del caballo), y el sesgo que el poeta da a la narración viene realzado por cuanto el amo del caballo desciende en campo no ya por la defensa del honor de una dama, sino para hacer frente a una demanda ocasionada por su violación. La ironía, subrayada por la rima entre 241a cermeña (v. i. 2.6) y d dueña (lo mismo que en el marco de la fábula aludida de la raposa y el cuervo, entre $1.443 \mathrm{c}$ monja y d toronja), trasciende al mundo caballeresco, que JR toma tan poco en serio.

A. En los apartados que siguen justificaremos nuestras enmiendas respecto al único testimonio, el del MS S, en las que vamos precedidos por los editores, que, cuál más (Cor.), cuál menos (Chiarini, ed. Milán-Nápoles. 1964), ajustan el texto al metro.

Adelantamos aqui que en lo morfosintáctico hemos suplido el artículo sustantivando denodado en 236a; hemos leído 241a valić y 242a tenié, y 245a cada día en lugar de $d e c$. $d$.; con proclisis en 2371: en lo léxico hemos reemplazado el corriente 242a dessolladas por essolladas, y, con Cor., compañón por el hipermétrico compañero. Contra Cor. admitimos el polisíndeton en $245 \mathrm{c}$, y eliminamos la prep. repeticla en 238a. También suprimimos el adj. 239a grand, que los copistas, particularmente S, tienden a introducir (cf., p. ej., 253a): alli mismo introducimos con el por del (con Cor.) por el ritmo. 
En la interpunción nos guiamos por la sintaxis; por el ritmo, en 236c: por la claridad, en 240 c.

B 1.1. El metro es regular si se reconocen las licencias que pueden verse marcadas en la edición de Cor. En 239c, sin embargo, preferimos derribó.l a derrbióle con sinalefa, y en 245 c "fuerça e elat e onra", admitimos la doble sinalefa, que Cor. quisiera eliminar omitiendo la conj. cop. $e$ ante edad (v. i. F 3).

1.2. La regularidad métrica implica enmiendas evidentes ya adoptadas por nuestros precursores respecto a los hipermétricos $239 \mathrm{a}$ grand, 239b enbargava, 24la valia, 243d compañero, 245a de cada día, y a la hipometria por omisión del art. en $244 \mathrm{~b}_{1}$; más otras enmiendas propuestas por nosotros, que afectan al hipométrico 236a "el muy denodado" (donde, para evitar la hipometria habria que leer muy como Tuy, bisílabo), y al hipermétrico 242a dessolladas, y al arritmico 242a "Tenía del grand yugo" (v, i. 3).

2. En cuanto al ritmo, si adoptamos el sistema que sugiere Navarro Tomás ${ }^{18}$ (págs. 60, 62 y sigs.). perfeccionado por Baehr ${ }^{14}$ (págs. 164-165), son trocaicos (con acento en 2. $.^{\mathrm{a}}, 4 .^{\mathrm{a}}$ y $6 .^{\mathrm{a}}$ sílabas) los hemistiquios $237 \mathrm{~b}_{2}, \mathrm{c}_{1}, \mathrm{~d}_{2}$, $238 \mathrm{a}_{2}, \mathrm{~b}_{2}$ (con apoyo en tan), c, d, 239a, b , c c , d $2,240 \mathrm{a}, \mathrm{b}_{1}, \mathrm{c}_{2}, \mathrm{~d}_{2}, 241 \mathrm{~b}_{2}$ (si se acentúa la prep. $a$; Ma si se acentuara la conj. $e$ ), c, $d_{1}, 242 \mathrm{a}_{1}$ (según nuestra enmienda, con acento en los artículos), 242 $b_{2}, c, 243 a_{2}, b_{1}, 244 a_{2}, 245 c$; son dactílicos (con acentos en $3 .^{a}$ y $6 .^{a}$ ) $237 a_{2}, 238 a_{1}$ (según nuestra enmienda; v. i. D 7.1), $b_{1}, 239 b_{2}, c_{1}, 240 b_{2}, 240 c_{1}, d_{1}, 241 b_{1}, d_{2}, 242 d_{2}, 243 a_{1}, b_{2}$, $244 c_{2}, 245 \mathrm{a}, \mathrm{b}$; son mixtos del tipo Ma (con acento en la $1 .^{\mathrm{a}}, 4 .^{\mathrm{a}}$ y $6^{\mathrm{a}}$ ) los vv. $237 a_{1}, b_{1}, d_{1}, 239 d_{1}, 241 a_{1}, b_{2}$ (v. s.), $242 b_{1}, 243 c, d, 244 a_{1}, b, c_{1}$, $\mathrm{d}_{1}$; del tipo $\mathrm{Mb}$ (con acento en la $1 .^{\mathrm{a}}, 3 \mathrm{a}^{\mathrm{a}}$ y $6 \mathrm{.}^{\mathrm{a}}$ ) los vv. $237 \mathrm{c}_{2}, 241 \mathrm{a}_{2}, 242 \mathrm{a}_{2}$, $d_{1}, 244 d_{2}, 245 d_{2}$, pero no $\sin$ plantear dudas, en primer lugar porque a veces las fronteras entre el tipo dactílico y el $\mathrm{Mb}$ se hacen imprecisas por el posible acento secundario que aflora en la anacrusis de aquél (cf. $240 \mathrm{~b}_{2}$ ). En $243 c_{2}$ "rixo bien tres vegadas", la diferencia entre $\mathrm{Ma}$, por el que hemos optado aqui, y $\mathrm{Mb}$ afecta al sentido (v. i. $D$ 6).

En $243 \mathrm{~d}_{2}, 244 \mathrm{a}_{1} \mathrm{~b}_{1}$, el apoyo en el adv. interr. dó asigna los cuatro hemistiquios que lo contienen al ritmo $\mathrm{Ma}$, con el acento secundario en el adj. pos. $t u$ en 244 ; con lo que toda la estr. (menos $244 \mathrm{a}_{2}, \mathrm{~T}$ ) si se prefiere la uniformidad a la variatio, vendría a constituir un ejemplo interesante de la repetición de ó o o para el énfasis, con o ó, también realzado por contraste.

18 Manual de Métrica española, Nueva York, $1966^{2}$, págs. 60-64.

14 Manual de versificación española, Madrid, BRH, 1970, págs. 96-97. 
3. Los vv. 245ab nos parecen compuestos de hemistiquios dactilicos, con el acento de aqui debilitado por el ritmo general del pasaje.

El v. 242a "Tenía del grand yugo dessolladas las cervizes" está evidentemente corrompido; según nuestra enmienda es trocaico en el primer hemistiquio (con un apoyo en el art. det.), y $\mathrm{Mb}$ o el tipo dactílico en el segundo, con sinafia entre yugo y essolladas.

Hemos asignado al tipo dactílico (o Mb) $240 \mathrm{~b}_{2}$ "e fincó el vencido" (v. i. C 2). Si se leyera "e fincó él vencido" habría dos acentos seguidos; lo que no es imposible (cf. 183c "al que mejor te sirve a él fieres quando tiras").

3.1. Las estrofas constituyen sendas unidades, excepto en 242-243, donde las cláusulas de los vv. 242b-d empalman con las de los vv. 234ab.

En 239a, el segundo arranque de la narración al principio de la segunda estrofa (v. s. 0.2.6), puede obedecer a la unidad de la misma.

3.2. Por lo demás, el trozo está caracterizado por la regularidad con que las pausas sintácticas coinciden con las versales, e incluso las pausas de variada entidad con la cesura (que, en rigor, deberiamos marcar con un espacio en blanco); entre los grupos sintácticos ajustados al hemistiquio (que por repetirse podriamos llamar de repertorio), señalamos $242 \mathrm{~d}_{1}$ "ojos fondos, bermejos", que reaparecerá en el v. 1.012c (en la descripción de la serrana monstruosa) ; lo hemos separado con (,) de $242 \mathrm{~d}_{2}$, aunque el término de parangón cuadra sólo a bernicjo (v. i. E 3.3). También hemos puesto (,) ante $242 \mathrm{c}_{2}$, para que sirva de remate no sólo del segmento que precede inmediatamente, sino de los otros dos anteriores. El v. 238d puede leerse con cesura de distinta entidad ; mayor, si leemos: "el asno con el miedo / quedó". siendo entonces con el miedo sintagma adjetivo (v. i. D 2.2); menor, si leemos: "el asno / con el miedo quedó"; con lo que tendriamos un complemento adverbial que modifica al verbo (v. i. D 2). Una alternativa semejante se da en 239a "Estava refusando el asno con la carga". Para 236 y 240c, cf., respectivamente, D 4.3 y 6 .

4. Las rimas representadas son en parte las corrientes: -ado (236), y nos preguntamos si es por tal facilidad por lo que se han trocado asno $\mathrm{y}$ caballo en 236d (v. s. 0.1.1), -adas (243), -ido (240), -ia (245), -illa (244); otras lo son menos, a saber, en orden de mayor a menor frecuencia: -(i)ente (237), -(u)eno (238), -izes ( 242 ; v. q. i. C), en $1.293 \mathrm{~d}$ también narizes: cervizes; el consonante -arga (239), inducido por carga, se da sólo aquí en todo el Libro por la limitada opción léxica. 
5. 240a "Ligero, apercibido" representa una de las numerosísimas parejas que coinciden con el hemistiquio y vienen como predispuestas para la cuaderna vía.

C 1. En la grafía y fonética observamos 241c acenia con [ni] por [ñ]. Al obliterar la diferencia entre 245 c edat e ib. salud, y más aún la que se interpone entre 242a dessolladas y c desolladas, por haberse neutralizado la oposición fonológica, renunciamos a lo que probablemente responde a una voluntad de variar. Debería estudiarse más de cerca el usus scribendi del copista.

2. En la fonética, 242c prizes (por prezes) rima con d perdizes; Cor. justifica la forma inflexionada en vista de priessa > prissa; Chiarini documenta la forma intermedia priezes. Para 242a dessolado $\sim$ essollado v. i. E 2.2.2. La forma 237c levar, sin palatalizar, era entonces corriente; el leonesismo 236c fraco es propio de S (v. q. 1.448c).

D 1. En vista de que la realización como sustantivos de formas que funcionan de por si como adjetivos, es en gran parte patrimonial y no productiva universalmente, por el uso predicativo circunstancial de $241 \mathrm{~d}$ "el sobervio", $1.405 \mathrm{~b}$ "el necio", es comprensible que S extrañara $236 \mathrm{a}$ "el muy denodado", transformándolo en "e muy denodado"; además de $241 \mathrm{~d}$ el sobervio hallamos la oración de relativo $245 \mathrm{~b}$ "los que son muy sobervios".

En 240b postulamos el uso sustantivo de vencido: "fincó el vencido", como en 1.203c "por ende non avía por qué lidiar con su vencido" (v. q. i. 3.1 , y cf. $1.428 \mathrm{c}$ "el vencedor a honra del precio del vencido", donde vencedor y vencido representan varios estadios de sustantivación, siendo la de aquél más clara por metaverbal; véase en la General Estoria, $4 .^{\mathrm{a}}$ parte, "esta piedad fizo allí el rey Ciro contrall rey Creso que non fue menos provechosa al vencedor que al vençudo" $56 \mathrm{v} 73$, que puede compararse con la realización sustantiva de $\operatorname{somet}(u)$ do en $4 G E$ "los sos sometudos e sos vasallos" 187r85, "(los romanos) que fueran vençudos e recibieran al rey e fueran sus sometudos" $154 \mathrm{v} 90^{15}$ (pero v. q. i. 4.1.1), 236b Aguisado funciona como sustantivo abstracto (v. q. 702a "oí dezir siempre de vos mucho bien e aguisado").

1.2. 242c Prizes (aquí realzado en su número por el adj. mucho), es un plurale tantum, como lat. preces; también lo es en el Libro, cervizes; $242 \mathrm{~b}$

15 Citamos esta parte de la General Estoria (en adelante GE, precedido del número de la parte) del MS Vat. Urb 536. Las citas de $3 G E$ las sacamos de nuestra transcripción; las de 2GE de la ed. de L1. Kasten ct al., Madrid, CSIC, 1957-1961. 
narizes puede asemejarse a un dual. El pl. en 237c "lorigas bien levadas" es, al parecer, estilistico (no puede ser distributivo porque remite a un sujeto singular); v. i. E 3.3.

Observamos el sing. en $244 \mathrm{~b}$ renzilla, que se aparta del pl. de $243 \mathrm{~d}$ empellada (v. q. i. E 3.2); de aquél se da también el pl. (cf. APal, citado por $D C E C H$, "questiosus 'con querellas e renzillas' "; c manzilla y d postilla, en cambio, se pluralizan en cuanto al efecto gracias al uso del sing. mucho.

2.1. Bajo la rúbrica del adjetivo pondremos la concomitancia entre las formas que lo son de suyo, y los participios adjetivados: 236a "sobervio... denodado", c "flaco ... lazrado", 240a "ligero, apercebido" (véase para éste $1079 \mathrm{~d}$ "que venga apercebido el martes a la lid"; $1570 \mathrm{~d}$ "vieja siempre por mí lazrada", para el uso verbal de lazrado).

2.2. La mayoria de los adjetivos se usan como predicativos; 240a ligero se abre hacia la función adverbial; sobre la naturaleza adjetiva o adverbial de los sintagmas con con o $\sin$ volveremos más abajo (v. i. 3.1 y s. B 3.2). De los adjetivos calificativos preceden al nombre, además de $238 \mathrm{~b}$, 242a, 245b grand(e), que casi siempre ocupa esta posición y llega a ser casi proclítico, 238a, 244a noble, y, a pesar de ser un part. adjetivado, 244 dorado; va, en cambio, pospuesto, como de costumbre, 239d, 243c necio. La ausencia del adj. grande, que $\mathrm{S}$ esperaba ante 239 a carga deja la descripción de ésta para el efecto.

3.1. Por darse por conocidos van acompanados de artículo determinado los nombres de los animales protagonistas, y por ser paradigmática en el cuento amoroso, 237b, 241d "la clueña"; queda asimismo actualizada la circunstancia, 239a "con la carga", el lugar, ib. c "en medio de la varga", el objeto de la acción, 241b "traer la leña".

El predicado nominal generalmente no va modificado: 240b "coidó ser vencedor" (v. q. i. 5.1.1), pero puede llevar artículo, y más cuando éste sirve para la sustantivación; por lo que podemos leer : $240 \mathrm{~b}$ "fincó el vencido" (v. s. 1.1 et i. 4.1.1).

Los nombres abstractos sujetos o precedidos de preposición no van actualizados : 245 c "que fuerça, e edad e onra ...", $i b$. d "vanse con mancebía".

El segundo término de la comparación normalmente va sin actualizar: 238c "como trueno", 242d "como pies de perdizes".

Para 237a "en campo", cf. MzPidal Cid 299.223, que equipara "en campo" y "en el campo"; pero téngase en cuenta que en campo equivale a en descampado; $238 \mathrm{~d}$ "con el miedo" (v. q. $87 \mathrm{a}, 302 \mathrm{a}$ ) se halla entre con miedo (cf. 339b "otorgáronlo todo con miedo ['amedrentados'] e amidos" y con 
el grand miedo (ci. 1426b "el mur con el gran miedo començóll a falagar" : pero también 182a "Con saña que tenía fizolo..."). De ahi que 239a "con la carga" pueda equivaler a cargado como forma analítica.

Notamos que los nombres del cuerpo y de las partes de él van precedidos de artículo determinado sin adj. pos., aunque se refieran al sujeto: $238 \mathrm{a}$ "Con los pies e las manos", 240c "en el cuerpo ... fue ferido"; v. q. 242ab, 243ab.

En 237c "lorigas bien levadas" y en las cláusulas que corren paralelas con 242 c "rodillas essolladas", la constr. abs. favorece la omisión del art. det., que también sería posible.

En las oraciones interrogativas del ubi sunt?, 244b "¿ dó es la tu sobervia?”, el art. det. reemplaza el adj. demostr. aquel, y queda eliminada la distancia temporal. Para la función anafórica del adj. pos., v. i. 4.1.2.2.

3.2. La frase sustantiva verbal 240 a dar salto se distingue de dar un salto, usado en $1.475 \mathrm{a}$ con el sentido actual; v. i. E 2.3.2.

4.1.1. El pron. pers. sujeto él expresaria contraposición implicita, para con el contricante, si leyéramos $240 \mathrm{~b}$ "coidó ser vencedor e fincó él vencido"; cf. GE Prov. 13:5 "mas el de sin piadad confonder la ha e será él confondido" (con realce del sujeto frente a Esc. 1.1.6 "mas el malo cofonde e será cofondido").

4.1.2.1. El pron. pers. átono se apocopa normalmente; por lo que leemos $239 \mathrm{c}$ derribóll y $243 \mathrm{v}$ vidolo, evitando la sinalefa innecesaria. También puede apocoparse con proclisis; por lo que en aras del ritmo (v. s. B 3) puede darse 237d "mucho delante l'iva ..." (cf., tras pausa, en Cid 853 "Váyante delant"); la otra lectura con pron. disyuntivo sería la más corriente (cf. 2 GE 1 Sam. 9:27 "Di al moço que vaya delant nos" $\leftarrow$ "Dic puero ut antecedat nos", y en el Libro 463bG "estando cerca d'ella", y no * "estándole cerca").

4.1.2.2. 240d "Las entrañas le salen" representa el uso del pron. átono en lugar del posesivo ante el sujeto, aquí el nombre de la parte del cuerpo acorde con los que vimos en 3.1 (para salir, absoluto, v. i. 5.2). En 243d "tus empelladas", el adj. pos. sirve para adecuar la acción por medio de un elemento nominal (en lugar del verbo o de la frase sustantiva verbal) a los nombres que siguen (v. q. i. E 1.5).

4.2. La función anafórica del adj. pos. se observa en $244 a$ “¿dó es tu noble freno e tu dorada silla?" respecto a 238 a "Con los pies e las manos e 
con el noble freno". En 244b y d el adj. pos. va precedido por el art. det., a diferencia de 244a. que acabamos de citar, evidentemente por el metro y tal vez también por variatio.

4.3. El indef. otro es plenamente pronominal en 236c, donde los dos adjs. se agregan como especificativos, tras pausa (pero véase el uso del adj. en 1440d "más que otro juglar", sin especificar).

5.1.1. En 243d-244ab se(e)r sirve todavia como verbo estativo, alternando con estar (para la sucesión desde ¿ó son? hasta ¿dónde están?, véanse los textos en nuestro ensayo sobre Jorge Manrique ${ }^{16}$ ).

Con el participio tenemos estar en 240d "estava muy perdido", que se alterna con $s e(e) r$ (cf. $588 \mathrm{aG}$ "de un dardo só perdido"; b. q. 247a. 544d et passim), y con perderse (cf. 461c "perdiame de sed"): indica el resultado frente al circunstancial sentirse (cf. 237c "muy valiente se siente"), y es correlativo de traer perdido (cf. $832 \mathrm{~d}$ "que lo traedes muerto, perdido e penado" ; para la modificación con muy, v. s. 6).

242a Tener es inducido por la presencia del part. (frente a aver en 1.012a “Avia la cabeça mucho grande sin guisa"); v. q. i. 5.3.

5.1.2. Fincar, generalmente semiauxiliar (cf. en un contexto parecido, $4 G E$ "e vençudo fincava él" $217 \mathrm{v} 27$ ), conserva algo de su sentido propio de 'quedar' en $240 \mathrm{~b}$ (v. q. 39c, 253d, 685b); por lo que puede acompañarse con un participio usado como sustantivo. En 244c bivir se halla entre el léxico y la sintaxis, como semicopulativo; v. q. 237c sentirse; $238 \mathrm{~d}$ Quedar, tiene valor autónomo.

5.2. 240d Salir representa el uso absoluto medieval frente a salirse, como caer (cf. 1145d) frente a cacrse (pero cf. 1441b "ovósele a caer").

Es intransitivo 242b inojar (v. i. E 2.3.2). Refusar, muy común como transitivo, aparece como absoluto en 239a "estaba refusando el asno con la carga", cuyo uso podría inferirse pasando por el que lleva complemento directo pronominal ; cf. $4 G E$ "non lo refusó mas plogol" 161r80, y comparándolo con desdeñar, que el propio JR empleaba como neutro: 610c "A penas de mil una te lo niegue, mas desdeña", y que en los romanceamientos biblicos hallamos por lat. renuere (cf. para la alternancia $3 G E$ Prov. $1: 24$ " $\mathrm{Ca}$ vos llamé e refusásteme" $\leftarrow$ "Quia vocavi, et renuistis", doncle en el romanceamiento anterior de Esc. I.1.6 se lee "desdeñésteme").

16 Para la secuencia ser/estar en la enunciación del tópico, cf. mi ensayo "Apuntes para el estudio de la trayectoria que desde el ubi sunt? lleva hasta el ¿qué le fucron sino ...? de Jorge Manrique”, en Thesaurus (1975), 3-51. 
5.3. La voz activa con sujeto impersonal se da en $241 \mathrm{~b}$ "a arar lo pusieron ...". La pasiva está representada por el participio en la construcción absoluta, 237c "lorigas bien levadas" (para 243b "las orejas colgadas" v. i.), y con función adjetiva por los participios que vimos en 2.1 , y por $236 \mathrm{~d} a r$ mado; en la forma finita, por $240 \mathrm{c}$ "de lança fue ferido", y, con verbo modal, por $240 \mathrm{~b}$ "e fincó él vencido" (si optáramos por esta lectura). Una componenda entre la voz activa y la pasiva refleja se da con tener en $242 \mathrm{a}$ "Tenié ... essolladas las cervizes", y en los versos siguientes hasta $243 \mathrm{~b}$, exceptuando $243 \mathrm{~b}$, donde colgado no puede conmutarse con la pasiva refleja, sino sólo con la activa de gerundio *"las o. colgando" (v. i. 9.1); lo mismo vale para 237 c "lorigas bien levadas".

5.4. En el paradigma notamos la forma etimológica del pretérito indefinido $243 \mathrm{c}$ vido, y de reir, rixo como dixo (cf. Cor.); 239d, 243d diz, forma apocopada de dize, puede interpretarse como un presente histórico (v. i. 5.7).

5.5. Además de la persona (él) están representados en el discurso directo las personas 239d (vós), de superior a inferior, y la persona (tú) entre iguales, con lo que queda marcado el tono del discurso por cuanto el interlocutor y el destinatario son los mismos intercambiándose las funciones.

5.6. El indicativo es aquí el modo exclusivo de la narración, y de la constatación en $245 \mathrm{~cd}$; el subjuntivo, de la moraleja, que se pone en forma exhortativa, en 244d, 245a; también aparece como optativo en $244 \mathrm{~d}$.

5.7. El presente es propio de ésta, como gnómico (236a-c, 245), de la conclusión en $241 \mathrm{~d}$, y de la estrofa introductiva, por ser ésta también doctrinal.

En la narración predominan el imperfecto, que denota acción progresiva contemplada en 237a, d, 238b, 239ab $\mathrm{ab}_{1}$, y sirve para describir un estado en 237c y lo que lo produce en $240 \mathrm{~d}$, y para poner al vivo el resultado en $238 \mathrm{c}$, $239 \mathrm{~b}_{2}$ (aqui alternando con el presente), $240 \mathrm{~d}_{1}$. El pretérito indefinido representa la acción puntual: $238 \mathrm{~d}_{1}, 239$ c, $240 \mathrm{abc}, 241 \mathrm{~b}$ (en 241a en oración subordinada temporal), 243c (bis), y el resultado visto del mismo modo: $238 \mathrm{~d}$ "no 1 fue bueno". 243d Diz alterna en las fábulas con dixo; cf. 285b. El pretérito se emplea también para acción anterior a otra de pasado: $237 \mathrm{~b}$ "porque forçó la dueña" ('habia forçado'). Por la escasez de tiempos compuestos y por el estilo de la frase sentenciosa no tiene alternativa $240 \mathrm{~b}$ "coidó ser vencedor e fincó el vencido", que en lugar de sucesión sugiere inmediatez.

En 237b "lorigas bien levadas", y en 343b "las orejas colgadas" contrasta con 748 c "la semiente nacida...", donde el part. indica anterioridad. 
6. 240c Fuerte desempeña el papel de adv. [de ahi la (,)]. 243c Bien al modificar "tres vegades" (y no "rixo") tiene valor enfático (cf. 410c respecto a $409 \mathrm{c}$ ).

243d, 244ab Dó ('dónde') tras pausa representa la forma intermedia entre $o$ (que JR conoce todavía) y dónde (v. s. 5.1.1, n. 12). Coexisten todavía como formas adverbiales 236a, 245b muy y 237d mucho (cf. 1.012 "mucho grande"), por lo que éste podria modificar a maldoliente, si no modificara a delante (v. s. 4.1.2). Ante $240 \mathrm{~d}$ perdido no esperariamos muy, si no fuera por el realce de la circunstancia personal (cf. en un plano más abstracto 701d "mi vida es perdida"). 241c $A$ veces está a caballo entre la loc. adv. y el léxico por cuanto puede significar 'por turno'; cf. Encina, Égl. Virg. 7.45 "cantar el canto a vegadas" $\leftarrow 18$ "alternis versibus contendere".

7.1. La prep. $a$, casi obligada ante compl. directo animado antepuesto, se da en 238c "a las otras bestias espanta", 239b "al cavallo embarga". No obstante, tenemos $\varnothing$ en $239 \mathrm{~b}$ "porque forçó la duela dueña el su señor valiente" (v. i. 11), y ante sustantivo abstracto en $244 d$ "Vengue la tu sobervia tanta mala postilla".

En 241c "a la noria", "a la aceña" la prep. $a$ no introduce necesariamente el lugar adonde, sino que indica el lugar en donde, como hoy "a la ventana".

Ante infinitivo tras verbo de movimiento la preposición no se había fijado aún; por lo que no es necesario pensar en una $a$ embebida en 237a "iva lidiar".

Las preps. de y con están sobrecargadas. En 241d "el amor de la dueña", $d e$ introduce un genitivo objetivo (antes se dijo 237b "porque forçó la dueña"); en 240 c introduce un complemento instrumental de medio o de modo: "de lança fue ferido": id. en el hipermétrico 242aS "tenía del grand yugo essolladas las cervizes": en $245 \mathrm{aS}$ de cada dia introduce como un aditamento más a la determinación temporal, por analogía con de dia, de noche.

En 245d "vánse con mancebía", con, sin dejar de ser comitativo, implica tiempo, 'al mismo tiempo que'; tras $236 \mathrm{~d}$ contecer indica relación interpersonal. En 242a "con el grand yugo" (restablecido por nosotros) la preposición introduce circunstancia concomitante (nás propio de la causa era por; cf. 227a); lo mismo podria decirse de 239a "con la carga", si no se considera sintagma conmutable con cargado (v. s. B 3.1), y de 244c "bivrás ... con mucha manzilla", donde la frase introducida por con puede ser sintagma (pero sin la correspondiente adjetiva). En 245b "los que son muy sobervios con su grand orgullia" podría introducir un complemento que explicara el adj. calificativo sobervio, pero también un tramo equivalente al primero, o sea : *"e muy orgullosos". 
Hemos asignado delante a la categoria del adverbio (v. s. 6). Morfológicamente es ambiguo en cuanto como preposición se usaba también por sí (lo que no reconoce $\mathrm{S})$; cf. 463b, 1.096a.

7.2. La repetición de la prep. ante cada miembro coordinado prevalece en el Libro; en 238a se da ante el primer tramo y el último (o sea, ante el segundo hemistiquio, tras la cesura), quedando los dos primeros unidos por su ausencia: "con los pies e las manos", según nuestra enmienda (v. q. i. F 2).

8. La conj. $e$, copulativa en 236a y c, alternando con $\varnothing$ en 240 a, es epexegética en 238d; para la repetición en 245 c, v. i. F 3. En 236a tiene valor adversativo. 241a Desque, 'desde que', introduce oración temporal. En 245c que puede introducir un discurso indirecto como objeto de lición (v. q. 252c), o ser conj. ilativa.

9.1. El discurso es paratáctico, con un neto predominio de las oraciones simples: 25 en un total de 28 , dos de ellas introducidas como discurso directo por el verbum dicendi, a las que pueden agregarse las oraciones que contienen construcción de infinitivo, 242b, 241b (bis), de participio (237b) y de gerundio (242 [menos d]-243b), y las que contienen una frase de relativo sin antecedente, en sustitución del nombre (245b).

Entre las construcciones participiales tenemos una moldeada al parecer en el ablativo absoluto latino: 237c "lorigas bien levadas ..." (v. s. 5.3). Entre los participios que dependen de traer ya hemos visto $243 \mathrm{~b}$ "las orejas colgadas", donde esperariamos más bien el gerundio * "l. o. colgando" (v. q. 5.3 y cf. $4 G E$ "e los razimos de piedras preziosas de muchos colores e de muchas naturas, e ivan por la tienda adentro colgando por ella” (183v57).

Sólo tres son oraciones compuestas propiamente dichas, con subordinada causal (237ab), temporal (241a), y consecutiva (238ac).

9.2. Predomina el asindeton, no sólo entre los tramos más extensos de la narración, sino también entre los breves (cf. 239bc, 240), y ante los verbos dezir (239d, 243d) y veer (243c).

La coordinación se hace por medio de la conj. cop. $e$, adversativa, según vimos, en 240b, y mediante la conj. 245 c que (v. s. 8), que traba la estrofa de la moraleja.

10. Predomina el orden $\mathrm{P}(\mathrm{S})$, con el verbo a la cabeza como es propio de la narración en 237a, 239a, 240a, 241a; en 241d, conclusivo, con relieve del contenido del verbo. El verbo impersonal en $236 \mathrm{~d}$ encabeza la oración; asimismo los infinitivos que inclican la acción a la que se destina el sujeto en $241 \mathrm{~b}$ (bis), 242b. El orden recto, SP, se da en los enunciados de la introduc- 
ción (236a-c) y en la moraleja $245 \mathrm{~cd}$, menos en la exhortación, ab, que pide el orden inverso.

Van antepuestos los advs., no sólo 244c siempre, 245a aqui, sino 236c ante, 237d delante, y el compl. especificativo en 236b, el de lugar en $240 \mathrm{c}$ (v. q. s.); con lo que la posposición queda para el énfasis: $243 \mathrm{c}$ "rixo bien tres vegadas".

$\mathrm{El}$ orden es inverso en las subordinadas, aqui en 238b, 237c "Lorigas bien levadas" con el participio pospuesto (asi también en 242c, 243ab (bis), como en 746c, que citamos en 5.7, pero frente a 1378a "passado el temor", que se aproxima a la prosa en cuanto al orden.

Si en el v. $237 \mathrm{~d}$, mucho, en lugar de modificar delante eleva el grado de maldoliente, nos hallamos ante un hipérbaton insólito pero no inusitado (cf. 2GE 1Sam. 1:16 "era grand el pecalo de los moços mucho delante Dios" $\leftarrow$ "erat etgo peccatum puerorum grande nimis").

11. Como las comparaciones abundan en las fábulas, señalamos aparte un ejemplo de comparación trabada por el verbo: $238 \mathrm{c}$ "que a las otras bestias espanta como trueno"; otra hay trabada por el adj. en $242 d^{17}$. Es implícita en 242c.

12. La sintaxis es culta: sin embargo, el latinizante 237c "lorigas bien levadas" (v. s. 9.1) ha de considerarse junto a las otras constrs. abs. de 242243ab, y a otras muchas en el Libro (y en vista de que tales construcciones se amoldan bien al hemistiquio (v. q. s. 5.7).

E 1.1. En el léxico, las palabras que se pueden agrupar en familias (con la consiguiente repetición del tema) están limitadas al núcleo de la moraleja; 244bd sobervia y $236 \mathrm{a}, 241 \mathrm{~d}$ sobervio, y a la parte sentenciosa de la fábula: $240 \mathrm{~b}$ vencedor, vencido; entre ésta y la narración, $245 \mathrm{c}$ fuerça y $237 \mathrm{~b}$ forçar se apartan en lo semántico (v. i. 2.2.2). Para $244 \mathrm{c}$ renzilla véase $205 \mathrm{~d}$ reñir 'quejarse' y $1620 \mathrm{c}$ reñidor. Para 237a faziente polríamos remitir al sentido del verbo (cf. $716 c$ "yo sé toda su fazienda e quanto ha de fazer") o más específicamente a 1173a fazienda 'batalla'. 242b Inojar comparte el tema con $409 \mathrm{~b}$ inojo (alli en rima). Para $243 \mathrm{c}$ reir podriamos recordar $1400 \mathrm{~d}$ risete, pero no risotada, muy posterior (DCECH: Acad. s. xix), que aqui englobaría la idea de 'repetición' (v. i. 2.1.1).

1.2. En la distribución de las especies gramaticales notamos sobre todo los nombres y adjetivos que resultan de trasvases de verbos e incluso repre-

17 Sobre las comparaciones en el Libro, cf. nuestro ensayo en Studies in Honor of T. Fotitch. Washington, Catholic University, 1963, págs. 279-301. 
sentan formas que tendriamos por tales (v. i. 2.1.2); para 360a "el muy denodado", véase 1001d "derribo'l si me denuedo".

2.1.1. En la formación de las palabras observamos la concomitancia de 241c, 243c vez y vegada (< lat. vg. *vicata), intercambiables aún en el $\mathrm{Li}$ bro en el interior del discurso; en rima y al final de la oración aparece la forma más sonante: 243 c "rixo bien tres vegadas".

2.1.2. Del participio de pasado, además de $240 \mathrm{~b}$ vencido y 236b aguisado (v. s. D 1.1), constatamos la realización sustantiva en $243 \mathrm{~d}$ empellada, del arc. empellar (v. q. empellón en APal. s. v. impingo: "dar e., lançar fuera"), y la adjetivación en denodado (cf. 285d "contra sí se denueda"), que en 236a se emplea sustantivado. 240b Vencedor, es una entre las muchas formas metaverbales presentes en el Libro, y susceptible de emplearse como adj. o como sust. La realización del participio de presente, 237a faziente, depende de su lexicalización; es muy próximo al verbo si puede compararse con dezidor en $7 \mathrm{~b}$ "que con ellos serías ante reis dezidores" 18 , en cuyo caso sería comparable con lat. biblico operans (cf. Prov. 13:4 "anima antem operantium impinguabitur"), con lo que tendría un significado circunstancial, de 'apto para cumplir (eficazmente) un cometido' (v. q. i. 3.2); también podría pensarse en una relación más estrecha con gradi en el ámbito del movimiento acción (cf. en el romanceamiento bíblico Esc. 1.1.6 (E, Prov. 3: 6 "e él (Dios) endereçrá tu fazienda" $\leftarrow$ "et ipse diriget gressus tuos"). Están lexicalizados como adjetivos $237 \mathrm{bc}$ valiente y d (mal)doliente.

2.2.1. 245b Orgullia aparece en rima (v. q. 214c "tanta es tu orgullia"), frente a orgullo en el interior del v. $(304 \mathrm{~b}, 1.223 \mathrm{c})$; pero puede asimilarse a $1.223 \mathrm{c}$ grandia y otros sustantivos abstractos en - $i a$, hoy en desuso, y a $245 \mathrm{~d}$ mancebia, 125 b quantía.

La enmienda de $243 \mathrm{~d}$ compañero para que se lea compañón, en aras del metro, propone una forma menos usual en el Libro (se da en rima, y sólo aquí y en $460 \mathrm{~b})$.

2.2.2. 240a Salto en la lengua arcaica y clásica abarca también el ámbito de 'asalto' (pero v. i. 2.3.2). 236d Contecer (y cuntir) sin $a$-, es la única forma que conoce JR y la corriente en la época. 242b Hinojar es otro hápax en el Libro; la forma parasintética de 410 b inojo seria ahinojar (DCECH lo cita $\sin$ doc.)., pero es sabida la poca fijeza del pref. $a$ - (v. q. i. 2.3.2).

En vista de la vacilación entre des- y es- (cf., p. ej., 249c despensa, 973a espender), aunque des(s)ollar es la única forma representada en los MSS (v. q. 507 c, 1217d, 1224a), hemos propuesto 242a essollar para el metro

\footnotetext{
18 Interpretamos dezidor como referido al sujeto, los discipulos.
} 
(v. s. B 2) y la variatio (v. i. F 4); excluimos la forma sin prefijo, que tenemos en cat. xollar 'esquilar', porque vendria a coincidir con cast. arc. sollar 'soplar'; cf. E6 Cant. 4: 16 "perfla" $\leftarrow$ "solla".

437b Forşar se distingue de esforşar (cf. 11b) por cuanto aquél se emplea para 'arrebatar bienes' (cf. 255b) o 'violar', como en 231c, a una mujer.

2.2.3. Mal- entra como prefijo asemántico (¿ocasionalmente intensivo?) en la formación de $237 \mathrm{~d}$ maldoliente ${ }^{19}$, variante de doliente (cf. 82a); et v. i. 3.2 .

En el sintagma 244d mala postilla, malo expresa una cualidad intrínseca (cf. 288b mal engaño), y sirve para trasladar postilla del sentido concreto de 'hinchazón, matadura, mal' (Cor.) a otro más genérico en el ámbito del padecimiento o de la desgracia.

2.2.4. La forma analítica de verbo + adverbio se da en $237 \mathrm{~d}$ ir delante (lat. praecedere).

2.3.1. Junto con la formación de las palabras cabe observar la alternancia entre sintagma copulativo y verbo simple; aqui $238 \mathrm{~d} s e(e) r(l e)$ bueno a uno comparable con el arc. provecer y con 256a aprovechar, y también entre traer + sust. y el adj.: 230a "sobervia mucha traes", 241d "el sobervio".

2.3.2. La otra alternativa era aver o tener pro (cf., respectivamente, 920 c, $1.170 \mathrm{~d}$ y $589 \mathrm{~d}$ ). La frase sustantiva verbal aparece en lugar del verbo simple en el caso de $238 \mathrm{~b}$ fazer sueno (aquí semideslexicalizado ya que permite la modificación de sueno) respecto a $164 \mathrm{c}$ sonar, 240a dar salto (v. q. $412 \mathrm{~b}$ "dio salto [la rana] en el agua"), respecto a $1208 \mathrm{~b}$ saltar; a la inversa, $245 \mathrm{~d}$ durar representa la forma simple frente a fazer dura (cf. Libro de miseria de omne 286c), y lo mismo puede clecirse de $238 \mathrm{c}$ espantar frente a $102 \mathrm{~b}$ poner espanto. Podría suponerse que entre $242 \mathrm{~b}$ hinojar y fincar $(f) i$ $n o j o(s)$ en $1.246 \mathrm{~b}, 1.096 \mathrm{~b}$ "el inojo fincado", hubiera correspondencia, pero aqui fincar no entra en una frase sustantiva verbal propiamente dicha. 245a Tomar lición se corresponde con alicionarse (más tardío y poco frecuente: $D C E C H$ : 1.628), mientras que ib. tomar enxiemplo existe sólo como sintagma (para en $(x)$ emplar 'difamar' cf. DCECH). También de 242c fazer prizes sólo se da en castellano la frase sustantiva verbal (el verbo simple era orar).

2.3.2.1. Posiblemente 239d buscar carrera larga era fraseológico; v. i. 4.2, donde también nos detenemos en el adj. largo.

19 “'A la muger mala non des suelta de mal fazer ¿̨o de malfazer?'. Más sobre bien(-) y mal(-) en un texto del s. xirl (Esc. I-I-6)", en Archivium, 26 (1976), 141-168. 
3.1. En la época de JR el campo léxico está bastante delimitado entre 239b andar y 237a ir. Entre traer y levar el punto de vista no surte un efecto siempre fácil de determinar : ante $241 \mathrm{~b}$ "a traer la leña" el lector u oyente se coloca en la escena descrita : 237c "lorigas bien levadas" hubiera podido admitir también el verbo traer, que predomina con nombres de prendas, $y$ de sentimientos y similares (cf. todavía en el Arcipreste de Talavera: "otros arreos desonestos que ellas traen" ${ }^{20}$ ).

3.2. 238a Freno puede referirse a las camas, unidas a las riendas mediante anillas (v. i. 3.3 et cf. MzPidalCid, s. v.).

Un problema de extensión semántica se da a propósito de bestia en $238 \mathrm{c}$ “que a las otras bestias espanta como trueno". Ya Isidoro en el tratado $D e$ differcntiis $(1,248)$ distinguia entre bestia y fera. Covarrubias en el Tesoro de la lengua castellana o española contrapondrá el significado más comprensivo de lat. bistia (fundándose en Cicerón, con el Calepino) al de su homólogo español: "ordinariamente se toma por los animales de quatro pies, corpulentos, de los quales unos son domésticos, como el asno, el mulo, el cavallo, etc., $y$ otros salvajes ferozes, como el león, el osso, el elefante". Si en el v. 238c va englobada la comparación con el león, que tradicionalmente es el que "con su ferocidad y braveza ... con el rugido sólo amedrenta a los demás animales" (citamos del Diccionario de Autoridades), se neutraliza la diferencia para con los otros equinos, y por la universalidad del término de comparación, los tres vv. se constituyen en una descripción per se: si, en cambio, bestia vale 'jumento', comprende al asno y no salimos del ámbito narrativo del cuento. 238b Sueno cuadra con c trueno, como 'estruendo' (frente a son, 'sonido armonioso': cf. 380c. 240a, 241a. Campo 'lugar amojonado para el desafio' (más tardio palenque), y 244a silla ('de montar') representan restricción semántica patrimonial (en ital., en cambio, sella/sedia).

Renzilla lo hemos relacionado con reñir (1.1), que en el pasaje aludido alterna con 203c querellar(se) 'quejarse', y apunta, por tanto, al deseo (en sing.) de recriminación o riña verbal más bien que de actos específicos de violencia; es eufemístico respecto a la acción del caballo en 239c. Para reñir, cf. los contextos respectivos en 205d "reñid, pues lo quesistes", 345d "e todo era reñir".

245c Edad requiere una glosa ib. d mancebia, por la que se confirma el sentido insólito, como haplológico ('la buena edad'), con que aparece aquí.

$V e z$ en 241 c "a vezes ... a vezes ..." entra en la bipartición de un conjunto cerrado (v. q. 397c, 1.231b) : en 242b "del inojar a vezes, finchadas las narizes", podria recobrar el significado etimológico de 'turno' (cf. lat.

20 Cf. la ed. de M. de Riquer, Barcelona, 1949, pág. 137.7. 
"rerum vices"), indicando la repetición, posiblemente relativa, o se emplea, al igual que en otros lugares del Libro, como una especie de litute donde esperariamos más bien a menudo (cf. 861b), o es un comodín para completar el cómputo de las sílabas.

La consabida extensión del adj. grande permite que se diga de $238 \mathrm{~b}$ sueno, 242a yugo y de $245 \mathrm{~b}$ orgullía (e induce al copista a interpolarlo ante 239a carga).

244a Dorado suele emplearse en correspondencia con aureus en la ac. de 'hecho de oro'; pero también puede corresponder a su étimo, lat. deauratus (cf. Isopet, que lo emplea junto a plateado; v. q. i. IV 1).

Si 237a faziente, que arriba (1.1) hemos relacionado por el tema con fazienda 'batalla', y por la formación con el contenido del verbo fazer, posiblemente adaptado a la circunstancia (2.1.2), lo relaciona Cor, con cat. faient 'simpático, que congenia con todos', aunque luego opte por el significado de 'activo, emprendedor'. En cuyo caso habria una restricción semántica (cf. fazañero respecto a fazaña), y podría postularse como uno de los epítetos del caballo (pero v. i. 3.3).

3.2.1.1. Un problema especial en el que no podemos entrar aquí es el significado de 239d varga, generalmente interpretado como 'cuesta'; pero no comprendemos cómo se pueda echar a un animal "en medio de una cuesta", por lo que nos inclinamos hacia la ac. de 'pradera' ${ }^{21}$.

Linda en la polisemia valiente, si en $237 \mathrm{~b}$, donde se dice del caballero, significa 'envalentonado' (en 189a "bien valiente" modifica "garçón loco"), y en $i b$. c, donde se dice del caballo, equivale a 'fuerte' (cf. lat. valere), 'que goza de buena salud' (v. q. 245c "salud e valentía", y 1159b "que si ende no muere quando fuere valiente"), y se contrapone a $237 \mathrm{~d}$ maldoliente. Pero también podría tener el mismo significado en los los vv. (cf. 312a "el león orgulloso con ira e valentía", clonde se aplica a un ser irracional).

237d (Mal)doliente en cast. equivale a 'enfermo' (cf. 373b); sin embargo, por la amplitud de dolencia, la forma compuesta también podría aplicarse a la falta de energía o firmeza concomitante con la causa (v. q. ital. malfermo).

3.2.1.2. La relación entre la abstracción y caso particular se da entre 245a en $(x)$ iemplo 'enseñanza' y la forma numerable $e$. 'apólogo'. Lo mismo diríamos con cambio de número entre $244 \mathrm{~b}$ renzilla 'litigiosidad (verbal)' y el pl. 'efectos de la misma' (v. s. D 1.2 et i. 3.2).

21 Además de $D C E C H$, cf. V. García de Diego en $B R A E, 38,215-234$, donde se documenta también barga 'tierra alagadiza'. 
3.2.1.3. Con el uso absoluto de 236a denodado (v. q. 1.435c) podemos comparar el uso relativo 1407a "Non deve ser el omne a malfazer denodado”. Para 293a refusar v. s. D 5.2; la interpretación 'recalcitrar' (Cor.) desharía la contraposición entre los andares rápidos del caballo y la parada del burro.

3.3. 237c Lorigas (para el pl. v. s. D 1.2), cuadra también a las caballerías ${ }^{22}$.

Noble, aqui y en los textos medievales, equivale a 'rico'; y por tanto puede decirse de las cosas, en $238 \mathrm{~d}$ del freno (v. q. 1.050b "noble ungento", $1.460 \mathrm{~d}$ "una copa de oro muy noble", $1.638 \mathrm{~d}$ "con su noble tesoro").

242d Fondo 'hundido' (junto con bermejo 'rojo') se dice de los ojos (que en 433a se describen en buen sentido como "someros"); 243a somido, de las ijadas; 243b agudo, del espinazo, o columna vertebral (en otros pasajes del Libro modifica a $267 \mathrm{c}$ navaja, $1217 \mathrm{c}$ cuchillo y $434 \mathrm{c}$ dientes).

De valiente vimos que se dice tanto de persona (237b) como de animal (c); v. q. 766b "carneros valientes vinieron bien corriendo". Si 237a faziente se toma como epiteto, deberia haber solidaridad con el sujeto (cf. carnicero en 226a "Alano carnicero"); es más probable que aquí se emplee como predicativo, y describa al caballo por sus andares o por su propósito, o más genéricamente por lo que iba a hacer (v. s. 1.1).

El verbo solidario con burro o asno, rebuznar, aparece en $894 \mathrm{c}, 1285 \mathrm{c}$, 1403a ; aquí tenemos, en cambio, el antropomórfico 243c reír. De 242a follar, que Cor. introduce con el significado de 'humillado, encorvado hacia abajo', no sabemos que pueda indicar el resultado de una acción sin que esté implícita ésta y la referencia a pie(s), como en lat. conculcare.

4.1. Al aparecer en pareja demuestran afinidad 245a ensiemplo e ib. lición (para aquél v. s. 3.1.2), 245c salud e valentia, 236a sobervio e ib. denodado, 236c flaco e ib. lazrado; se complementan 240a ligero e ib. apercebido. Vemos como poco probable la complementariedad entre $243 \mathrm{~d}$ empella$d a$ pl. y $244 \mathrm{~b}$ renzilla (v. s. 3.2 ).

4.2. $239 \mathrm{~d}$ Largo, dicho de la carrera, se opone a estrecho (cf. $116 \mathrm{c}$ buscar senda por carrera y 637c "desviada estrecha"); por lo que la intimación del caballo no ha de interpretarse con 'largaos de aqui' (largarse, muy pos-

22 Lo atestigua para el catalán, con el sentido de 'defensa de mallas', M. de Riquer, L'arnés del cavaller. Armes i armadures catalanes medievals, Barcelona, 1968, págs. 68 y 136. Recordamos en sentido inverso que guarnicion(es) podía guiar la armadura del caballero; cf. en el Poema de Fernán González 315cd "nunca de cavalleros tales golpes se vieron, / todas sus guarniciones nada no les valieron". 
terior, es de origen náutico; cf. DCECH); $237 \mathrm{c}$ valiente, si se emplea en el ámbito de la salud (v. s. 3.2 ), es opuesto a $237 \mathrm{~d}$ maldoliente, y en sentido absoluto a $240 \mathrm{~d}$ perdido.

4.3. Forman series dentro del mismo campo semántico 238a pies y manos, 244a freno ... silla, 240b coidar, 243d dezir. En la categoría de los adverbios, para 239b “(andava) mal e poco”, recuérdese el análogo tarde o nunca (cf. 256d "tarde cumplen o nunca").

4.4. Pertenecen al mismo campo semántico $239 \mathrm{~d}$ carrera, ib. b andar, 237 a ir y 238d quedar 'pararse', y los nombres que hemos visto, referidos a las partes del cuerpo y a las labores del campo. 237b Dueña se distingue, por el rango social, de 409b mujer.

5.1. En cuanto al nivel del vocabulario y fraseologia, nos parece significativa la presencia del adjetivo atributivo noble, dicho por dos veces de 238a, 244a freno, y el afín (v. s. 3.2.5.1) dorado, dicho de 244a silla. Si los sumamos a frido, que aparece en otras fábulas como más allegado al étimo en lugar de frío (cf. 1425 "en la frida montaña"), y, por otro lado, a $244 \mathrm{~d}$ vengar 'castigar' como latinismo semántico crudo (adelantamos aquí que el Isopet de Lyon lo traslada a la lengua corriente: 5-6 "Vostre meschance/ bien me vange").

Al ámbito culto pertenece trueno, no en sí (cf. 1286d), sino como término de comparación en 238c "espanta como trueno", si pensamos en RVg II 1.22 altitonans, en celisonans o summus tonans, que es como se llama a Dios en el himno litúrgico Aeterni caeli gloria, fundado en la imagen bíblica (cf. 2GE "e tronará sobre ellos en los cielos" 214a10). Para la diferencia de nivel compárese asimismo $255 \mathrm{~d}$ "mas ansí te secarás como rocío e feno" con 400b "como huerco las tragas", de la increpación afectiva a la muerte.

5.2. No faltan, sin embargo, como en el resto del Libro, las expresiones de la lengua corriente, como 244 d mala postilla o 24la no valer una cermeña, que se alinea con tantas frases que indican menosprecio, $239 \mathrm{~d}$ buscar carrera larga (especialmente si es fraseológico; v. s. 2.3.2.1), 240d estar muy perdido (v. s. D 6), que contrasta con la sentenciosidad retórica del v. b.

F 1. Como en las demás fábulas, y más a menudo que en algunas otras, observamos aquí la repetición de sonidos consonánticos, con finalidad aliterativa, consciente, al parecer, en 237d "delante ... doliente", 240c "fuerte ... fue ferido", 242a "rodillas desolladas", c "ojos ... bermejos", ib. d "pies de perdizes", 243a "salidos, somidas", 244c "mesquino, con mucha manzilla"; 
obsérvese también la repetición de la misma vocal en $243 \mathrm{~d}$ "conpañón soberbio, ¿dó son?". A los que se suma como incontrovertible la figura etimológica vencedor, vencido en $240 \mathrm{~b}$.

2. Agréguense la disposición $X Y X$ en $241 \mathrm{~b}$ "a arar lo pusieron e a traer la aceña", y el paralelismo con anáfora en 243d-244ab, con quiasmo en 243a, realzando el tópico del ¿ubi sunt? En 238a la disposición es de miembros crecientes: "Con los pies e las manos e con el noble freno" (para S, v. s. D 7.2); v. q. 244 c, que citamos arriba.

3. El polisindeton en $245 \mathrm{c}$ "que fuerça e edad e onra" se destaca en la moraleja contra el fondo de una narración caracterizada por el asíndeton (v. s. 10.2).

4. La variatio está representada en la sintaxis en $244 \mathrm{ab}$ por la ausencia del art. delante del adjetivo posesivo y presencia del mismo (en $244 \mathrm{~b}_{1}$ por nuestra enmiencla): en el léxico, posiblemente por 242a essollado (si se acepta nuestra enmienda) e ib. c dessollado. Cabe volver aqui sobre la duda que hemos expresado arriba acerca de la diferencia o unidad de significado de valiente en $237 \mathrm{~b}$ y c. Su diferencia favorecería la variatio ; su identidad pondría de relieve la unidad entre el animal y el hombre.

Parece contradictoria del horror aequi la repetición de asno en 238d, 239a "el asno ... quedó ... / Estava refusando el asno ..." (para los posibles motivos extrinsecos v. s. B 3.1), y de 239bc "al cavallo embarga. / Derribóll el cavallo", pero junto con otras repeticiones similares (cf. 234lbc, 301bc) hemos de reconocer en ello una de las características de la fábula.

A. Aquí, como en otras fábulas, según ya demostraron Tacke y Lecoy, JR depende esencialmente de la reelaboración mediolatina en verso, llamada Aesopus communis o Aesopus Neveleti (por el nombre de su primer editor), ya atribuida a Gualterio el Inglés (GI). Lecoy señalaba (pág. 126) los pasajes siguientes: 240b "coidó ser vencedor e fincó (e)l vencido" $\leftarrow 17-18,240 \mathrm{~d}$ "las entrañas le salen" $\leftarrow 12$ "viscera rupta [patent]"; en 244 ab, el topos bubi sunt? y en la moraleja los vv. $245 \mathrm{~cd} \leftarrow 21-22$. Es presumible que JR conociera la fábula también en su forma que hemos llamado "escolar", en prosa.

No son menos llamativas las diferencias para con los modelos latinos conocidos; por lo que queremos dejar constancia de los hitos principales de la tradición, que nos permitirán caracterizar la reelaboración de GI y establecer cuáles son los elementos exclusivos de GI, tanto en el contenido como en la forma, y luego hacer lo mismo para con el texto vulgar. 
1.1. Empezaremos recordando que entre las fábulas "esópicas" originales, o sea, las de la colección griega más antigua llamada "augustana", no hay ninguna que se le corresponda plenamente. En la reseña de F. Rodriguez Adrados aparece, pues, como "no H(ausrath)", con el n. $109^{23}$.

Tampoco se halla en las colecciones existentes de los continuadores, en latín, la de Fedro, el liberto de Augusto, y en griego la de Babrio (fl. antes de 207 d. C. ${ }^{24}$.

1.2. Son numerosas las fábulas que narran desventuras de animales y esclavos en términos análogos, ilustrando la fatuidad $\mathrm{y} / \mathrm{o}$ la envidia.

Entre las de Fedro hay una en que aparece un corcel de carrera, coronado de victorias, que un tal se llevó y vendió para las labores del molino ("in pistrinum vendidit”); viendo acudir al circo a sus congéneres más afortunados, el caballo lamenta su suerte inmerecida ${ }^{25}$. Para nuestro propósito, sin embargo, sólo tiene valor comparativo, mientras no se demuestre que trascendiera a la tradición medieval.

En otra fábula, que Rodríguez Adrados no sólo relaciona con la nuestra, sino que considera como la forma original, o sea, la que reseña como H 272 (3, pág. 255), se narra de un caballo que, tras haber gozado de bienandanza por el cuidado que le prodigaba el amo, es descalabrado a golpes cuando éste, hecho caballero armado, lo empuja en lo más violento de la refriega. La buena suerte y la desgracia son vistas por los ojos del burro, aquélla con envidia, ésta con compasión. Por mediación de Bisancio, esta fábula pasaria a una fuente latina, "que a todas luces resulta conocida por el Arcipreste" (Rodríguez Adrados², pág. 464).

1.2.1. Los problemas de la "tradición fedriana" planteados y en parte resueltos por el mencionado investigador en una obra tan erudita como compleja, nos atañen también como antecedentes de situaciones que se repetirán a lo largo de la historia, por cuanto la afirmación de Fedro, pról. 1, 1-2,

23 Vol. 3, pág. 331. Cf. A. Hausrath, Corpus fabularum Aesopicarum, 2 vols., Leipzig, 1956-57, donde reproduce los códices en que se conservan las fábulas atribuidas a Esopo en las colecciones siguientes: I, "Augustana", que recibió su forma definitiva en el s. v; II, "Vindobonense", fijada en los ss. VI o vII, y "Accursiana", del s. IX; C. Halm, Fabulae Aesopicae collectae (Leipzig, 1852), se basa en la "Accursiana". V. q. E. Chambry, Aesopi fabulae (París, 1925-1926).

24 Cf. la ed. de B. E. Perry de Babrius and Phaedrus (Londres y Cambridge: Loeb Classical Library, 1965), y del mismo la colección de textos que ocupa el primer tomo de su monumental historia (inacabada) de la tradición de las fábulas, Aesopica (Urbana: Universidad de Illinois, 1941), de la que iremos citando. Para la bibliografía, cf. la ed. de Fedro, de A. Guaglianone (Turín, 1969).

25. Se halla en el Appendix perottina (recopilada h. 1463 por el humanista italiano que le dio su nombre) y lleva el n. 21 ; cf. Perry, Aesopica, n. 549. 
"Aesopus auctor quam materiam repperit / hanc expolivi versibus senariis ${ }^{26}$, y la otra advertencia (en pról. IV, 11) de haber escrito fábulas aesopias "al estilo de Fedro" (que ha suscitado el espinoso problema "fuentes" vs. originalidad, posiblemente a partir de máximas de la diatriba cínica), podrian asumirse como paradigma de las vicisitudes de la tradición medieval, que, junto a la dependencia (indirecta) de Fedro, delata la de otras fuentes, especialmente bizantinas, y no excluye tampoco la originalidad ${ }^{2 \tau}$.

1.2.2. No podemos terciar en la controversia de si Fedro representa la primera manifestación latina de la fábula esópica o si hubo también un Aesopus latino, en prosa, hoy perdido, que $\mathrm{G}$. Thiele postula e intenta reconstruir, en dos recensiones distintas, que publica por separado ${ }^{28}$. Nos limitaremos a nombrar los textos a los que nos referiremos luego.

1.2.2.1. Como antecedente de las colecciones medievales conocidas se propone un Aesopus llamado ad Rufum por la carta de "Esopo" a su maestro Rufo (Xantus), que acompaña a los testimonios más antiguos. Junto a este texto supuesto, que Thiele llana "Ur-Ronulus" o Protorómulo, se sitúan dos códices, el Vossianus 15 de la Biblioteca Universitaria de Leiden, escrito por el monje Ademar de Chavannes en 1025, Ad, muy próximo a Fedro por incorporar en parte el Phaedrus solutus (la redacción seguida de Fedro), y el Wissenburgensis, de Wolfenbüttel, Gud. lat. 148, del s. XII, transcrito por Gude, W; pueden verse reproducidos, respectivamente, por L. Hervieux bajo los nombres de Fabulae antiquae y Phaedrianae fabulae ${ }^{28}$.

1.2.2.2. Para una segunda etapa en la tradición latina se postula un texto llamado Romulo por el nombre del "autor" de un prólogo incluido en códices más recientes, y que, además, de textos prosificados de Fedro, o atri-

24 Como curiosidad notamos la correspondencia en contrario de Lba 116: "tomé senda por carrera", con Pról. III, 38: "Ego poro illius semita feci viam", aunque el contexto sea totalmente distinto.

27 Para una visión compendiada, ef. H. C. Schnur, Fabeln der Antike (Munchen, 1978), Introd., e id., Lateinische Fabeln des Mittelalters (ib., 1978).

${ }_{28}$ G. Thiele, Der lateinische Asop des Romulus und dic Prosafassung des Phaedrus, Heidelberg, 1910; reimpres. Hildesheim, Zurich, New York, 1987. Su tesis la evalúa Rodríguez Adrados, junto con C. Zender, Der lateinische Aesop des Romulus und die Prosafassungen des Phädrus (Heidelberg, 1910), y M. Nøjgaard, La Fable Antique (Copenhague, 1964-1967), en 1, pág. 141, pero concluye que "Este nombre (de Acsopus latimus) no significa otra cosa que fábulas griegas traducidas al latin y ausentes de $\mathrm{Fe}-$ dro (o presentes en éste en otra versión distinta)", 2, pág. 503.

${ }_{29}$ Les fabulistes latins depuis le siccle d'.4uguste, París, 1883-1899, 5 vols. (el vol. 1. con la descripción de MSS e incunables; el vol. 2, con la transcripción, no muy de fiar, de los textos que aqui interesan; Ad y W se hallan en las págs. 131-156 y 157-192). 
buibles a Fedro, contiene las fábulas del pseudo-Dositeo (anteriores a 207 d. d. C.), y fragmentos de otras colecciones.

Con el nombre de Rómulo ( $\mathrm{R}$, también para el pl.) se designan las colecciones conservadas, en primer lugar el códice burneianus de la Biblioteca del Museo Británico, lat. 59 (B en el aparato de la reconstrucción critica de Thiele de una de las dos recensiones en que subdivide la tradición latina).

Con Hervieux lo llamaremos Romulus vulgaris (RVg.) por su gran difusión. Está dividido en cuatro libros, mientras que Ad carecia de división, y W constaba de cinco (cf. Hervieux, 1, 195-233). RVg. ${ }^{2}$ valdrá para la forma resumida en verso, "Romuli vulgaris breviatae fabulae", Oxford, Corpus Christi 86 (Hervieux, ib., págs. 246-261).

$\mathrm{La}$ "recensio gallicana" en la que Thiele coloca RVg. (que designa con la sigla B) comprende, entre otros, al códice Ashburnhamianus, que Hervieux llama Florentinus por conservarse en la Biblioteca Laurenciana de Florencia, n. 1.555, RF, págs. 474-512. La "recensio vetus" abarca, entre otros, el códice Vindobonensis de la Biblioteca Estatal de Viena, lat. 303, RV (v. i. 3.3, n. 35, y cf. Hervieux, págs. 417-454).

2. Puestos ante una tradición muy compleja, que reclamaría un estudio de las etapas más recientes y cercanas a JR, sin terciar en el problema de modelos eventuales desconocidos, transcribiremos los textos principales e intercalaremos luego el cotejo de las colecciones que acabamos de mencionar, W (Hervieux, pág. 135), RV (ib., pág. 470), RF (ib., pág. 494), Vicente de Beauvais (ib., pág. 240), como ilustración de una serie de opciones menores, y para enuclear en $\mathrm{R}$ unos términos de comparación con GI, y directa $o$ indirectamente con el propio JR.

2.1. Como término de comparación último nos referimos a Ad, que entre 67 fábulas contiene 37 del corpus de $\mathrm{R}$, mientras que las demás representan una redacción en prosa de Fedro (Phaedrus solutus); entre ellas está la nuestra, por lo que puede suponerse que sea una de las fedrianas que no han llegado hasta nosotros ${ }^{30}$. Advertimos de paso que en Ad falta el promitio (que en Fedro era una innovación acorde con el carácter pragmático de los romanos). El texto (n. 31 en Ad) es el de Perry Aesopica, donde lleva el n. 565 .

Insolens faleris asino occurrit equus, qui fatigatus malis transeunti tardius dedit viam. "Vix" inquit "me teneo, ut non te rumpam calcibus". Reticuit ille et gemitu testatur deos. Equus currendo ruptus parvo in tempore ad villam est missus. Hunc onustum stercore ut vidit asinus, tali eum irrisit verbo: "Quid tibi, gloriose quondam, faleris? Modo ad contemptam redisti miseriam."

so Perry, loc. cit. (v. s. n. 22), la incluye en el apéndice, en versión inglesa, con el n. 535 . 
Felices, qui ullum despiciunt, dubii meminere debent quia nesciunt quid futuri sunt.

2.2. El texto de $R V g$. (3.3) lo transcribimos de Hervieux (pág. 214) cotejándolo con las variantes del aparato de Thiele (B), e introduciendo iuventa por iumentam (RF y RV iuuenca). La numeración es la de Thiele. Cuando la comparación es para con GI, nos referiremos al R(omulo) de la tradición galicana.

De temporibus et fortunis audiamus scriptam fabulam. Qui se sciunt esse felices nulli faciant iniuriam, dubiumque esse meminerint quicquid est in fortuna positum, ut hec fabula narrat.

'Equus quidam, ornatus freno ex auro et argento, sella et nacco pretioso. ${ }^{2}$ satis decorus membris iuventa occurrit asino in angusto ${ }^{3} \mathrm{de}$ longe venienti et onusto, ${ }^{4} \mathrm{et}$ quia illi transeunti tardius dederat viam "eo quod ex itinere lassatus erat, dixisse equus asino fertur: ${ }^{6}$ Satis me, inquit, teneo... Nam te calcibus rumperem, 'qui obvianti mihi non redisti aut stetisti. ${ }^{8}$ Terrore illius et superbię causa tacuit miser asellus, ${ }^{9}$ [et cum gemitu testatur deos]. Deinde non longo post tempore ${ }^{10}$ equus ruptus currendo, nullam iam habens diligentiam, ${ }^{11}$ macer effectus est. Iubet dominus ut ducatur ad villam ${ }^{12}$ et portet stercus in agros. ${ }^{13}$ Accepit ornamenta rustica et onustus ibat per semitas. ${ }^{14}$ Asellus ille in prato pascens agnovit equum iam infelicem, quem tali sono increpat: 15 -Quid tibi profuerunt illa ornamenta pretiosa, ut talem haberes audaçiam? ${ }^{16} \mathrm{Nunc}$ et tu modo nostris fungeris rusticanis officiis. Num quid modo habes audaciam?

Ammonet omnes hęc fabula, ne quis in potestate sua velit aliquos terrere.

2.2.1. Aunque posterior, y no traducido sólo de $R V g$. (en sus variantes representadas por S, Ulm, 1476), interesa para la comparación, de prosa castellana a verso, el texto de Isopet, que reproducimos del incunable de $\mathrm{Za}$ ragoza, $1498^{31}$, donde ocupa los fols. $44^{\mathrm{v}}-45$ y lleva el número 3 del libro $3 .^{\circ}$, con la rúbrica: "La tercera del caballo e del asno e de los tiempos e fortunas." Entre ésta y el texto lleva un grabado de madera que representa el encuentro del caballo, con todo su arnés, y el asno cargado de un saco, en el trazado de un camino evidentemente demasiado estrecho para ambos. El caballo, en ademán de querer proceder sin tropiezos, además de la silla con su ación y estribos y petral, y del freno con su barbada, lleva collera, al parecer de metal, como también lo serian las anillas que unen lomeras y ataharres (el llevar atacola y el ir recogido el copete y trenzadas las crines demuestran el cuidado de que era objeto).

Este es el texto, ligeramente adaptado en la grafía y enmendado ${ }^{32}$ :

31 A saber: Esta es la vida del ysopet con sus fábulas historiadas, Zaragoza, Juan Hurus, 1489; ed. facs. Fábulas de Esopo, ed. de E. Cotarelo y Mori, Madrid, RAE. 1929. Véase la descripción en Hervieux, 1, págs. 421-423, a la que Cotarelo, evidentemente, no tuvo acceso.

32 Corregimos cuidado para que se lea cuitado. Por si interesa a los bibliófilos, ad- 
Los que se veen en prosperidades non deven fazer injuria a alguno, e deven conoscer que la rueda de la fortuna es dubdosa e se puede mudar, segund nos enseña esta figura. Un caballo fermoso de cuerpo nuevo, muy ornado, apuesto e adreçado de guarniciones argentadas e doradas, se encontró en un camino estrecho con un asno, el qual venía cargado de luengas tierras. E porque non le fizo lugar prestamente sinón despacio, porque venía cansado, dizese que le dixo el cavallo: - Maravíllome cómo non te despedaço de coces, porque non me fiziste lugar para que pasase, e aun devieras estar e quedar mientra que yo pasava. El cuitado del asno, espantado de la sobervia del cavallo, callando entre sí, gemiendo, se quexa de los dioses. Después, antes de mucho tiempo, el cavallo corriendo reventó de manera que se non pudo reparar, e así enflaquesció, que non pertenescia a su señor; por lo qual mandó que lo levasen a su heredad para levar e carrear estiércol para las tierras e viñas. Por que el cavallo, dexados los arreos plateados e dorados, huvo de tomar albarda e aparejos de trabajar, e assí se iva cargado por esos caminos e senderos. E el asnillo mesmo pasciendo en un prado, conosció al cavallo; al qual d'esta manera maltrató e denostó : - ¿Qué te aprovecharon aquellos ornamentos e guarniciones para que me ovieses menospreciado en aquel tiempo, tomando tan grand sobervia e osadía contra mí?; agora usa como yo d'estos nuestros oficios de aldea. ¿Dónde es agora aquella tu sobervia e silla tan preciosa, aquella tu guarnición dorada?: ¿dónde es tu fermosura de cuerpo? Todos tus bienes son tornados en mezquindad e desaventurança.

Enséñanos esta fábula que el poderoso en el tiempo de su prosperidad non deve menospreciar al pobre, porque si cayere, non se escarnesca d'él; antes deve fazer bien e ayudar al pobre, porque quienquiera puede venir a seer pobre.

2.3. Pasamos ahora al texto difundido en la Edad Media con el nombre de Romulus o de Liber Aesopi o Aesopus communis (v. s.), y conocido por antonomasia como el libro (le livre). Le cuadra también el nombre genérico de $I \operatorname{sopet}(e)$; así el propio JR en 96d, si alli se refiere a él, y no en general a las fábulas esópicas en otra cualquiera de las formas que revistieron en la Edad Media.

W. Förster en su edición critica lo publica como anónimo ${ }^{\text {s3. Prevaleció }}$ luego la atribución a Gualterio el Inglés (en adelante GI), tras identificarle Hervieux con Waltharus o G(u)alterus Anglicus, religioso inglés, capellán de Enrique II de Inglaterra (1133-1189), encargado por éste de enseñar letras a Guillermo, su futuro yerno, que iba a ser rey de las dos Sicilias ${ }^{34}$. Si de tal circunstancia surgió la transfusión en versos elegíacos de las fábu-

vertimos que el error no aparece en el texto enmendado de la edición de Sevilla (J. Cromberger, [1521]), Libro del sabio c clarissimo fabulador ysopo hystoriado e annotado, fol. xxxiv-xxxir. Alli los grabados son similares pero de moldes distintos, más toscos.

3s En su edición de Lyoner Yzopet (Heilbronn, 1882), donde se halla en la segunda parte, pág. 96 y sigs.

34 Cf. Hervieux, 1, pág. 494. Para otras atribuciones, cf. C. Filosa, La fazıla e la letteratura csopiana in Italia dal Medio Evo ai nostri giorni, Milán, 1952, págs. 6-12. 
las, ésta se colocaria antes de 1177, fecha del matrimonio real; por ser Gualterio también autor de un libro titulado Pro latinac linguae exercitiis, se comprendería también mejor el génesis y la finalidad de la versificación.

En la serie de 60 ó 62 fábulas que contiene ${ }^{35}$, la del caballo y el asno aparece con el número 44 en la mayoría de los códices, entre los que Hervieux eligió el MS BNP, lat. 14.381 ${ }^{36}$, escrito en Francia en los ss. xII-xIV (pág. 316 y sigs.), y Förster, el MS BNP, 151.315 (P), aun reconociendo una distancia considerable para con el arquetipo (pág. XIII) ${ }^{37}$.

Fue transcrito centenares de veces y se conservan numerosísimos MSS en muchas bibliotecas de Europa; también gozó del favor de la inırenta ${ }^{3 \times}$. El proceso de corrupción del texto empezó desde muy pronto, también por la abundancia de glosas interlineares y marginales, ocasionada por la dificultad del dictado en algunas fábulas, como la nuestra ${ }^{30}$.

Nosotros no hemos hecho una búsqueda sistemática, sino que, además de los textos susodichos, hemos cotejado los MSS y ediciones que nos venían a la mano, en Italia (Venecia: Marciana, MSS 4.018, 4.538 ${ }^{40}$ : Brescia. $1.487^{41}$ ) y en España (BNM, 141 y $110^{42}$ ), para comprender las dificultades que los copistas pudieran tener para elegir un texto lo más cercano posible al que conociera JR. Este es, pues, el que proponemos como hipótesis de trabajo sobre la base del MS BNP, lat. 14.381, elegido por Hervieux (pág. 337):

1 Gaudet equus faleris, freno sellaque superbit; ista quidem vestit aureus arma nitor.

Obstat asellus equo; vicus premit artus asellum, vexat onus, tardat natus eundo labor.

35 La ausencia en algunos MSS de las fábulas 59 (De indeo et pincerna) y 61 ( De cive et equite) la justifica Förster por su carácter más propio de los fabliaux. Al reducirse a 60 , las fábulas corresponden a tres libros de $\mathrm{R}$, divididos en grupos de 20 fábulas.

se Cf. Hervieux, 1, págs. 511-514, donde se describe entre otros muchos mss. del original latino $y$ de las traducciones.

87 Los otros códigos que trae a colación para el establecimiento del texto son: BNP, $8509^{\mathrm{a}}$, también francés, ss. xıI-xIV; G, Wolfenbüttel, 87, 5, alemán, s. xIII; V, Viena, v. s. 2.2.2., escrito en Francia sobre antígrado alemán, ss. XII-XIV, con el texto del Rómulo de las fábulas 1-16 intercalado; L, Lyon, 57, s. xiv, con traducción francesa.

38 Cf. Hervieux, 1, págs. 503-602; para las ediciones, cf. págs. 602-635.

s9 No sabemos que se haya hecho un estudio como el texto se merece.

40 Cf. Hervieux, 1, págs. 595-597; ambos son del s. xiv.

41 Cf. ib., pág. 600.

42 Cf. $i b$., págs. 583-584, uno del s. xIv; el otro, incompleto, del xv; e Inventario General de MSS de la BNM. Madrid, 1953. Hervieux registra también otro, de la Academia de la Historia, MS 45, en letra italiana del s. xv, Para otros MSS habría que proseguir las investigaciones que hiciera (de segunda mano) G. C. Keidel en "Notes on Aesopic Literature in Spain and Portugal during the Middle Ages", Zeitschrift für romanische Philologic, 25 (1901), 721-730, empezando por los catálogos de incunables (para España también el del s. xv de F. Vindel), en los que menudean los "Esopos". 
5 Quod sibi claudit iter, sonipes inclamat asello:

-Occurris domino, vilis aselle, tuo.

Vix tibi do veniam de tanti crimine fastus; cui via danda fuit libera, dignus eram.

Supplicat ille minis, instatque timore silendo;

10 fit timor et surda preterit aure minas.

Sessor equi declinat equo; dum vincere temptat vincitur, et cursu viscera rupta patent.

Privatur faleris, freno privatur honesto; hunc premit assiduo reda cruenta iugo;

15 huic acuit terga macies, labor ulcerat armos Hunc videt, inque iocos audet Asellus inhers:

-Dic, sodes, ubi sella nitens, ubi nobile frenum? Cur est hec macies, cur fuit ille nitor?

Cur manet hic gemitus, cur illa superbia fugit?

20 Vindicat elatos iusta ruina gradus.

Stare diu nec vis, nec honor, nec forma, nec etas sufficit in mundo; plus tamen ista placent.

Vive diu, sed vive miser, sociosque minores disce pati: risum det tua vita mihi.

25 Pennatis ne crede bonis; te nulla potestas in miseros armet; nam potes esse miser.

9 instatque: mutitque; 11 sessor: dominus; 12 cursu: cursum / patent : negant ${ }^{48}$.

2.3.1. De entre las numerosas versiones que se hicieron nos referiremos ocasionalmente a las francesas, conocidas con los nombres de Isopet de Lyon, Isopet I e Isopet III de Paris, siendo éste una versión parcial en prosa del Isopet $I^{44}$ y una vez a una de las italianas (v, i. 3.1 .2$, n. 47 ).

2.4. Aunque interese menos porque no hay indicio que JR lo conociera, no estará de más mencionar tambièn el texto de otro inglés, Alejandro Neckam (1157-1207), que reelaboró la fábula en verso, en una versión estilizada, más fiel al contenido de $\mathrm{R}$ y más fácilmente comprensible que la de $\mathrm{GI}^{45}$.

48 Las principales variantes que registra Förster, pág. 121, afectan a las lecciones siguientes: 1 "sella frenoque" I.; 2 nitor G] decor P, color V; 5 quid V; claudit II L.] claudat $\mathrm{P} ; 7$ fastus $\mathrm{P}$, faustus $\mathrm{L}$; 9 minis $\mathrm{Pl}$ timens $\mathrm{V}$ : instatque L] nutatque $\mathrm{P}$. minuitque, $\Lambda$; silendo] gemebat $V ; 10$ fit timor $P \Lambda]$ tucior; 11 temptat GVL $\Lambda$ ] certat PII ; 12 cursu L] cursum cett., - patent L] negant cett.; 13 frenol auro P; 14 hunc] nunc $G ; 16 \mathrm{H}$. u. inque] $\mathrm{H}$. n. huncque, Huic temptare $\mathrm{L} ; 17$ sodes] sedes $\mathrm{L}$, sonipes (i; 18 cur est hec] Cur hoc est $\mathrm{L} ;-$ cur] quod L; - fugit] fuit LI[1 (fugit $\mathrm{M}^{2}$ ), - ille] ante I.; 20 iusta] ista L; 21 forma] uita L; 22 placent] uigent L; 23 s. u. miser] sed me miserum II ; 24 det] dat II $\Lambda: 26$ potest esse miser $\mathrm{H} \sim \mathrm{m}$. e. p. cett.

44 Cf. ib., pág. 635, y J. Bastin, Recucil général des Isopets français (París, 1930).

45 Cf. Hervieux, 1, págs. 668-684; 2, pág. 409 (texto). 
Sirve de comentario de éste cuando escribe 18 "Victores magnos orat adesse deos", y de una de las variantes cuando llama al asno 7 " animal servum natumque labori".

Con $\mathrm{R}$ reitera la mención de las guarniciones ("ornamenta") de los buenos tiempos (v. 8) y de las otras de que el caballo es privado en su desgracia (v. 22); como Gi, renuncia al otro juego de palabras entre rumpere y ruptus ( $\mathrm{R})$.

Con un fin evidentemente moralizador, amplía el discurso del caballo para demostrar su orgullo desmesurado (cf. 11 "Me reveretur homo, dominator totius orbis"). Parece reflejar el topos del "mundo al revés" cuando afirma que el caballo se habia hecho no ya "compañero" del asno (según veremos en GI), sino siervo suyo: 23-24 "Quid tibi pompa brevis, quid gloria tam fugitiva / prodest, cum servus factus es ecce michi?”.

Ante la pregunta tradicional, "Quid tibi ... prodest?", introduce, con el mismo sesgo, la interrogación tópica del jubi sunt?: 21-22 "Ubi sunt nunc aurea, dixit, / ornamenta quibus nuper eras tumidus?".

El ornato retórico se manifiesta en el poliptoton: 1 "Fortis equus misero currens occurrit asello", y la figura etimológica : 20 "Vilia portabat stercora vilis equus".

2.5. Entre los textos vernáculos que JR pudo conocer recordaremos el Isopet de Lyon, del s. xim, redactado en el dialecto de la Franche-Comté (v. s. n. 31). Tacke cree ver filiación directa en los primeros versos (fáb. n. 44):

Un valat pormoinne un Cheval

Per la citey lou contreval.

$\mathrm{Y}$ en el discurso del asno y moraleja final; a saber, en los vv. 47-50 y 65-66:

Di moi, fait il, cheval vaillanz,

Qu'estoies si soresaillanz,

De la selle ou est la noblesce,

Et dou froin dorey la richesce?

Honours et beautez et juenesce

Durent trop pou, si fait proesce.

2.6. En Inglaterra hubo, además, otra tradición, encabezada por el Romulus anglolatino, que no ha llegado hasta nosotros, pero que se puede reconstruir por otros textos, uno de los cuales, que suele llamarse LBG por los lugares donde se hallan sus más importantes MSS (Londres, Bruselas y Göttingen), deriva del Isopet de Maria de Francia ${ }^{46}$. Hervieux lo estudia bajo el

46 Cf. la ed. de K. Warnke, Dic Fabeln der Maric de France, Halle, Bibliotheca Normannica, VI, 1898, y la bilingüe de H. U. Gumbrecht, Munchen, 1973. 
título de Romuli anglici cunctis exortae fabulae o "Derivado completo" 4 . A nosotros nos interesa como ampliación en prosa (no sin puntos comunes con GI).

3.1.1. Fijándonos ahora en el contenido de $\mathrm{R}$ y comparándolo con Ad, o sea aqui con Phaedrus solutus, constatamos que la colocación del protagonista a la cabeza de la fábula contrasta con el texto de origen fedriano, que empieza por una fórnula de carácter poético, "Insolens faleris". En la enunciación de las guarniciones, en lugar de "nacco" se lee en $\mathrm{RVg}^{2}$ un inverosímil "sella decorus ex auro" : en LBG, "sella deaurata".

Unos particulares que no se hallaban en Ad, son la prestancia del caballo: RVg, "satis decorus membris iuuenta", donde, para JR hemos rechazado la variante $\mathrm{RVg}$ iumentum (v. s. 3.2), la procedencia desde lejos del asno y la estrechez del canino.

La circunstancia, que ya Ad indicaba, "asino ... qui fatigatus malis transeunti tardius dedid viam", reaparece como "racionalizada", en R, como motivo del desabrimiento del caballo. La idea de 'ir de paso' (transire), que acabamos de ver, se halla en todos.

Característica de la prolijidad de $\mathrm{R}$ es la introducción del verbum dicendi, con referencia, según vimos, a la tradición: "dixisse fertur" (Isopet: "Dízese que le dixo"), frente a $\varnothing$ en Ad. Común a todos es la frase "Satis (Ad: vix) teneo", con variantes que unen la frase a lo que sigue. Vicente de Beauvais: "Nisi me satis continerem".

No parece casual, en vista de otras repeticiones que sirven para contraponer el "antes" y el "después", la de rumpere (RV, disrumpere), primero en la amenaza del caballo (donde también se da en Ad), y luego en la descripción de su descalabro ("ruptus"), como para realizar verbalmente el dicho "derisores deridentur" ("el alguazil alzuazilado"), que aparece en el sobrescrito de la fábula en RV. (El juego de palabras quita relieve a la acción de currere, determinante en la otra fábula, pero ajeno a las costumbres medievales, en que se cuenta cómo el caballo había participado en las carreras de cuadrigas.)

Por lo demás, en $\mathrm{R}$ (y no en Ad) la increpación del caballo, "qui obvianti mihi non redisti aut stetisti", vuelve sobre la parte ya narrada, hasta con el mismo nexo de relativo.

La reacción del asno se introduce en $\mathrm{R}$ a modo de glosa, con una alusión a la causa del sobresalto: RV, "territus superbia illius" (Isopet: "espanta-

47 (f. ib., págs. 775-793; 2, pág. 628 (texto). Para otra visión más problemática, cf. Rodríguez Adrados, 2, págs. 287-290. 
do de la sobervia del caballo"), que posiblemente es elaborado con endíadis en $\mathrm{RVg}{ }^{2}$; RF, "Terrore (itaque) illius et superbia"; más discursivo, $\mathrm{RVg}$ : "Terrore illius et superbiae causa".

En Ad, donde falta el segmento que acabamos de indicar, ya se lee que el asno calló y gimiendo apeló a los dioses: "Reticuit et cum gemitu testatur deos" (cf. otra de las no muy frecuentes alusiones a los dioses en Fedro, I, 17,9 "haec inquit merces fraudis a superis datur"). Isopet, que contiene la traducción completa, al parecer por $\mathrm{RVg}$, agrega un "entre sí" a callar (o ¿a gemir, para eliminar la leve contradicción entre el silencio y la invocación a los dioses?).

La razón de la desgracia del caballo la indican tudos, incluso Ad, como "ruptus currendo". En R, sin paralelo en Acl, se indica el breve espacio que intercorre entre el incidente en la carrera y el envío del caballo a una finca o campo. Macies o macer es de $\mathrm{R}$ para describir la condición segunda del caballo, y cuatro de los testimonios agregan la causa: "nullam habens diligentiam": el amo no se cuida de él. Isopet, después de poner como definitivo el percance del caballo, "de manera que se non pudo reparar", tras la descripción de su delgadez, "así enflaquesció", indica la consecuencia con un poco claro "que no pertenescía a su señor" (¿traducción torpe o texto lagunoso?).

Nótese en $\mathrm{R}$ la mención (retardada) del amo, "iubet dominus ut ducatur ad villam et portet stercus in agrum ... et onustus", cuando en Ad bastaba "ad villam est missus. Hunc onustum...", y que onustus (RV, oneratus) ya se había dicho del burro: una vez más $\mathrm{R}$ manifiesta su tendencia a la contraposición por cuanto también ornamenta había aparecido arriba: "accepit ornamenta rustica" (Isopet explica: "el cavallo, dexados los arreos plateados y dorados huvo de tomar albarda y aparejos de trabajar").

Para el contacto, introductor del desenlace, que en Ad no podría ser más conciso: "Hunc onustum stercore ut vidit asinus", $\mathrm{R}$ indica el lugar (el prado donde pacía el asno), menciona el reconocimiento ("agnovit") e introduce lo que sigue con el verbum dicendi (increpare, en los más).

En R vuelve a aparecer el epimitio de Ad (presentado como moraleja “Ammonet ..."). El promitio va dirigido contra los poderosos, para que no aterroricen a los inferiores desde lo alto de su poder. La incertidumbre acerca del estado futuro es común a $\mathrm{R}$ y Ad. Vicente de Beauvais hace más explícita la imagen de la Fortuna: "dubianque meminerint esse Fortunae rotam" (v. q. Isopet).

3.1.2. No sabemos que se haya estudiado sistemáticamente el nexo de GI con R ( ¿y Ad?). De modo empírico podemos afirmar que la redacción en verso (también la (le Neckam) conserva los hitos principales de $R$, con los cambios que comportan la implantación de los sintagmas nominales y la 
eliminación de los elementos terciarios, de espacio y tiempo, o la reducción de los mismos a elementos secundarios.

Parece arrancar de Ad cuando empieza por la arrogancia del caballo que se enorgullece de los ornamentos de las guarniciones, designados aqui con el nombre específico de falerae, como en Ad; lo que no le impide señalar aparte el freno y la silla, como en $\mathrm{R}$ (con el desplazamiento, en algunos, de los metales preciosos de falerae a los frenos y hasta a la silla).

Con los predecesores GI tiene en común el encuentro frontal, que se expresa no en el v. correspondiente, 3 "obstat asellus equo", sino retrospectivamente por las palabras del caballo, donde GI emplea el verbo occurrere, como R y Ad más arriba.

En el v. 4 "ceundo" parece traer el eco de R (y Ad) "transeunti", pero trasladado a utro contexto. Su interpretación depende de la ambigüedad de natus / nactus (como 3 artus / arctus, que, sin embargo, es univoco en el contexto). En Marc. 4.538 eundo iba precedido de la prep. in, borrada luego; con in el gerundio designaba la circunstancia: 'la fatiga se le había recrecido al asno andando' (¿ como reminiscencia de R lassatus?); en cambio, natus 'nacido', con eundo como término, 'para andar', describe al asno como animal servil (según lo daba a entender explícitamente Neckam; v. s. 2.4).

La increpación del caballo es menos extensa que en la fábula de Neckam, pero más explícita que en $\mathrm{R}$, como afirmación de su superioridad y de su derecho a la prioridad en el paso.

Ha desaparecido en GI el testari deos de R y Ad. Como GI, en otros lugares no rehuye las reminiscencias paganas (cf. 20a 2 "supplicare Iovi"), sería posible pensar aquí no en una omisión, sino en una sinopsis de la expresión original: "supplicat minis", 'el asno suplica, pero al mismo tiempo apela a los dioses'; con lo que se explicaría más fácilmente el v. 10 "surda praeterit aure minas": 'el caballo no presta oido a la apelación a los dioses': de hecho, así interpreta el Isopet de Lyon, vv. 21-32:

Outre passe (li asne), cline la face: n'est autre semblant qu'il en face.

LBG, si vio "supplicat minis", lo comprende en el sentido más obvio de 'suplica ante las amenazas': "A sinus ... nec minaci equo respondere ausus est”, y hace decir retrospectivamente al asno: “et me sub onere gravi fatiscenten minis ferocibus terruisti".

Por lo demás, el verso en cuestión da pie para múltiples variantes que cambian el sentido, no sólo por reemplazarse "minis" con timens (V), sino porque "nutatque timore silendo", si hemos de aceptar con Förster esta lección de $\mathrm{P}$ como la auténtica, se presta para múltiples variaciones, entre las que "motusque timore gemebat" (V) es la única que conserva la idea de 
gemitus de R y Ad. Las otras, como "nutitque" $(\mathrm{H})$, que viene a hacer doble empleo con silere, y BNM 110 "mittit (silendo timore)", se explican como transformaciones de "nutat"; en el incunable de Brescia se lee: "minuitque silendo timorem". Nosotros hemos preferido aquí (pero como mera hipótesis) "instatque" (L), como más próximo al castellano de JR.

En $R$ y Ad no había transición alguna entre las dos partes de la fábula. GI la suple con unos versos que también han dado pie para una plétora de soluciones distintas. Ya indicamos nuestra incertidumbre ante 10 "surda praeterit aure minas", de sujeto no muy evidente: si éste es el asno, primero se dice de él que vacila ("nutat") o se calla ("mutit") o se para (instat), y luego que no escucha.

Las palabras que preceden, "fit timor", se hallan en la mayoría de los textos que hemos consultado (incluyendo a $\mathrm{P}$ y $\mathrm{H}$ ). Las hemos aceptado por lo que se verá luego en el texto castellano, aunque constituyen una repetición algo torpe de lo que se acaba de decir sobre el miedo del burro. Pero si timor puede considerarse con valor metonímico por la situación que lo causa (con fit como en 28.2 "fit mora"), el sintagma podría introducir, según la otra hipótesis que indicábamos arriba, la reacción del caballo, que, sordo ante las amenazas, se abalanza hacia su ruina. Förster, contra el propio P, prefería la lección "Tucior", que tampoco nos parece muy clara en cuanto a la sintaxis y al sentido; la señalamos porque por antifrasis pudo sugerir a JR el comentario 238d "e no-l fue bueno".

En el arquetipo, la lección 11 "Summus equi declinat honor" constituye una digna preparación para introducir el dicho sentencioso "dum vincere temptat ...". En el soneto que acompaña la fábula en el incunable de Brescia, la introducción de poi, 'después', marca el sucederse de los hechos: "Fortuna poi volgie mantello".

Entre esto y la traducción italiana en prosa, "e scendette il cavaliere del cavallo acciò piú ratto passasse e vincesse la gara" ${ }^{48}$, hay toda una serie de interpretaciones que presuponen en el original las variantes Dominus, como en $\mathrm{H}$, o sessor (como en Marc. 4.538; BNM 110 Sexor), y tal vez preparen la introducción de 1 valat en el Isopet de I.yon, ¿y de 237b señor en el Libro?

Un equu corregido en equo en Marc. 4.538 podría sugerir que el copista pensara en "declinat equum", como si el amo rechazara al caballo en consecuencia del demacramiento, según lo que hemos visto en RV "ex macie despicitur" (v. q. I.BG "a domino suo neglectus").

R Equus ruptus, que Neckan evitará, pasa a 12 "cursum viscera rupta negant", en la var. de L que transforma en "curso r. v. patent”, con una evi-

48 Cf. el Esopo volgarizzato, ed. P. Berti, Padua, 1711, pág. 99. 
dente bajada de tono y un realismo que debía de ser muy congenial a los narradores medievales.

GI respeta la contraposición entre las dos partes del cuento, por la alusión a 13 falerae (v. s. 3.1.2) y, por medio de una metonimia acumulativa, a ib. aurum (var.). El verbo 14 premere tiene ahora como objeto al caballo, en 3, al asno.

Mientras que los efectos de la tarea rústica a la que es sometido el corcel tras su derrota se multiplican por segmentos de verso (y nombres abstractos; vv. 14-15), como arriba en la descripción de las angustias del asno, el segundo encuentro entre los dos protagonistas se describe con suma brevedad: 16 "hunc vidit". Sigue la indicación de la osadía de la burla asnal: "inque iocos audet asellus inhers" (Ad, más directo: "tali eum irrisit verbo"), preparando el tratamiento de que el caballo vencido es objeto por parte del burro como si perteneciera a su casta: 17 "Dic, sodes", donde sodes podría resumir R "Nunc et tu nostris uteris nobiscum officiis rusticis" (citamos de $\mathrm{RF}$; véase el Isopet: "agora usa como yo d'estos nuestros oficios de aldea”). Más abajo el asno aludirá a sí mismo entre los 23 "socii menores".

El discurso del asno con el tópico del ¿ubi sunt?, desarrollado aqui en dos tramos (v. 17), y con la contraposición entre la bienandanza de antes y la desgracia de ahora, en otros cuatro (vv. 18-19), de movimiento encontrado, en tiempo presente (18 "est"), pasado (ib. "fuit"), y vuelto hacia el futuro (19 "manet"), mal se compagina con ese desarrollo rápido hacia el desenlace que debería caracterizar al cuento esópico. La sucesiva consideración sobre la fugacidad de los bienes de este mundo (vv. 21-22) va acorde con la inclinación medieval hacia la amplificación (v. q. Neckam), pero es poco compatible con el epíteto de inhers, 'necio', que GI, acorde con la tradición, atribuye al asno.

La idea de la fugacidad de los bienes del mundo viene a lo mismo que la de la volubilidad de la fortuna (cf. el promitio de R y el epimitio de Ad), aquí aludida por la imagen de las alas, 25 "pennatis ... bonis" (para la figura retórica (v. i. 3.2.2. F 3). Sigue la exhortación a la condescendencia para con los menores (ya hemos aludido a la expresión "socii menores"; v. q. 26 miser y cf. RV inferior), motivada de un modo parecido a Ad.

Como suplemento propio, GI intercala en la moraleja la aplicación $e$ contrario al caballo de la idea de rita brevis sed felix $: 23$ "Vive diu sed vive miser", para regocijo y burla del que fuera antes su víctima.

3.2.1. No estarán de más algunas consideraciones sobre la lengua de los dos textos latinos, que haremos siguiendo algunos de los mismos apartados que adoptamos arriba.

$\mathrm{R}$ se caracteriza en la morfosintaxis por el uso de angustus como sust., 
por ausencia de limes: 2 "in angusto"; $|6|$ por el uso del adv. satis como ponderativo (cf. cast. assaz) : 2 "satis clecorus", y también con el valor de vix, 'a duras penas': 6 "Satis me teneo"; [] por la abundancia de preps.: 3 "de longe venienti" ; 5 "ex itinere" ; 9 "cum gemitu", epim. "in potestate sua", y por la confusión de los casos tras algunas de ellas: 9 "post tempore" (11 "ad villam" era del lat. fam.; cf. Cic., epist.); y [8] por usar indiferentemente 4 quia (más familiar en lat. clás.) y 5 quod.

Refleja la prosa narrativa latina en el uso de constrs. participiales: 14 "in prato pascens", 10 "nullam iam habens diligentiam", 3 "de longe venienti" (frecuente en la Vulgata; cf. Is. 10:3), 4 "illi transeunti", 7 "obvianti mihi", a las que se suma una de gerundio: 10 "currendo" (sólo este y 7 estaban en Ad), y sobre todo en la pergeñación de las oraciones compuestas (1-5, 9-11 y 14; con unión de rel.). Al incremento de la subordinación respecto a Ad ha de restarse "Vix, inquit, me teneo, ut te non rumpam calcibus", que en RVg suena: 6 "Satis inquit, me teneo ... Nam te calcibus rumperem", con una pausa que podría interpretarse como de aposiopesis.

La inclusión del verbum dicendi en el discurso clirecto en 7 , que acabamos de citar, "Satis me inquit teneo", es normal en la prosa clásica y no representa artificio.

E. La gama léxica es más amplia que en $\mathrm{Ad}$; $\mathrm{RVg}$ se distingue por el término poco corriente 1 naccus 'gualdrapa', que la mayoría de los $\mathrm{R}$ omiten, como un hápax en lat. tardio (Thiele).

[1.1.] Del mismo tema aparecen 13 rusticus y 16 rusticanus. [2.1.1.] Son simples 6 tenere refl. (RF continere), 6, 10 rumpere, pas., cl., 'desgarrar', 7 stare 'quedarse quieto': el compuesto 11 efficere, pas., está por fieri (cf. Thiele). Como forma más cercana a las lenguas vernáculas, $11 \mathrm{ma}$ cer se aparta de 69.18 macilentus, cl. 14 Infelix representa un estado circunstancial, por lo que puede modificarse con iam. [2.3.1.] Notamos la frase sustantiva verbal 16 habere audaciam (= audere), que admite la combinación libre, "ut talem haberes audaciam"; 10 habere diligentiam, aunque no constituya sintagma, transforma alicui esse diligentia, quedando reemplazado el caso oblicuo, e instaurado el sujeto personal. [3.2.] 4 Sonum está por verbum (cf. Thiele); accipere en 13 "accepit ornamenta rustica" portria tener un sobretono irónico si se piensa, p. ej., en Vegecio, accipere loricam; sin embargo, su empleo por assumere es muy frecuente en latín tardío; cf. Vulgata, Sab. 15:8 "post pusillum ducit se unde acceptus est" $\leftarrow$ E6 "e depués un poco torna a aquello de que fuera tomado".

[4.] Aparecen en serie como alternativas 7 redire y stare ( $\mathrm{RF}$ puntualiza: "obvianti mihi in alteram partem non declinasti, aut stares ut transirem". 
F. La figura de suspensión o aposiopesis que hemos creído ver en 7 "Satis me... teneo", si es tal (cf. Virg. E 1.135), delata el intento retórico de imitar el habla viva. Notamos similicadencia en $2-3$ "in angusto ... et onusto", propia de la prosa literaria del latín tardio, si aqui no es fortuita.

La descripción del caballo 2 "et decorus membra iuventa" recuerda Virg. E 4.559 "et crinis flavos et membra decora iuventae" (cf. Thiele).

G. Por la "manera de traducir" que veremos luego en JR bajo el apartado que sigue a $\mathrm{F}$, ponemos aquí unas consideraciones estilísticas. Hay anpliación en 15 "Quid tibi profuerunt illa ornamenta pretiosa ut talem haberes audaciam?", que trasladado luego al presente, suena: 16 "Num quid modo habes audaciam?" (RV, aún más prosaico, agrega: "Quibus me despexisti, audaciam multam habens"; Isopet: id.). Es evidente el contraste con Ad "Quid tibi gloriose quondam faleris?", que ilustra cómo la concisión e in cisividad del texto más antiguo se diluye en $\mathrm{R}$.

H. la narración viene caracterizada por el nombre del protagonista a la cabeza ${ }^{49}$, seguido de quidam, que aquí se corresponde con el art. indeterminado de las lenguas modernas. El contenido del cuento se da como narrado previamente: 5 "Dixisse equus asino fertur". Entre las dos partes agonales hay una clara determinación temporal, que denota la secuencia: 9 "Deinde non longo post tempore". El tiempo es el pasado, entreverado de presente histórico en 11 "Iubet dominus ...".

3.2.2. B. El dístico elegíaco, elegido por GI, y antes por Aviano, no era el metro más adecuado para la fábula esópica, y predisponía a una elaboración artificiosa. 15 Terga (var.) es irregular ya que sería violento el alargamiento de $-a$ en ársis (v. i. F 5). Por lo demás, la técnica métrica de GI ha de juzgarse según los cánones posclásicos ${ }^{50}$. La variedad en la realización saldrá a relucir en la comparación con la cuaderna vía de JR.

49 Nøjgaard (v. s. n. 26) hace observar justamente que la fábula de tipo esópico no suele empezar por la indicación espacial, sino por el personaje, respecto al que aquélla tiene un carácter meramente auxiliar, o para poner de relieve los elementos significativos (2, pág. 238); cf. Isopet, I, que concuerda con la tradición: "Uns biaus chevaus et gros et lés, / bien enfrenés, bien enselés", y, en el Libro, entre otros exordios, 199a "Las ranas en el lago ...", 1.437a "la marfusa un día con la fambre...".

50 Entre las peculiaridades de la métrica posclásica se cuenta la brevedad de la vocal - o en la terminación verbal, incluyendo al gerundio, el alargamiento de la sílaba breve ante cesura. Con razón señala Schnur que los versos de GI han de juzgarse en comparación con las moralitates que se agregaron a las fábulas (cf. Hervieux, pág. 354 y sigs.; la de nuestra fábula en la pág. 361), que, con su latín bárbaro, revelan también la nérdida de conciencia de la cantidad de las sílabas. 
D. En la morfosintaxis, GI coincide incidentalmente en 3 "Obstat asellus equo" con la concisión de Ad "asino occurrit equus", pero 6 "Hunc vidit" frente a Ad "Hunc onustum stercore ut vidit asinus" ya nos da la medida de la diferencia que separa la concisión del verso del movimiento de la prosa narrativa, más aún la de $\mathrm{R}$ y de las reelaboraciones.

La concisión se conjuga a veces con la oración compuesta : 5 "Quod sibi claudit iter, sonipes inclamat asello", 8 "Cui via danda fuit libera, dignus eram"; pero aun asi GI dista a todas luces, p. ej., de LBG "qui transeunti michi debitum facere nescis honorem, dando locum et vacuando viam transeuntibus artam", que aducimos aquí como ejemplo extremo de reelaboración prosística.

Observamos incidentalmente que corren paralelos 16 audere in y 26 armare in, ambos cs., aquél con antecedente virgiliano. El tiempo del verbo es uniformemente el presente, excepto en el retrospectivo 18 "cur fuit ille nitor?".

En GI la brevedad se cifra en la predilección por oraciones brevísimas, como 10 "fit timor" (cf. 28.2 "fit mora"), que van parejas con la parataxis, y con el asindeton, tanto en la narración (cf. 3-4) como en la moraleja (25-26). $\mathrm{Al}$ repetirse de una fábula en otra se revelan como caracteristicos del artificio gualteriano, y más cuando van subrayados por contraposiciones abruptas y disposiciones quiásmicas.

Dejamos al lector la comparación GI parataxis / R subordinación, GI asíndeton / $\mathrm{R}$ unión, que se deduce de las respectivas descripciones.

GI difiere de $\mathrm{R}$ especialmente por cuanto su estilo es eminentemente nominal, con lo que esto comporta en la pergeñación cle la frase: en 12 "et cursu viscera rupta patent”, cursus desplaza el verbo currere de R; v. q. 7 "Vix tibi do veniam de tanti crimine fastus", en cuyo pasaje correspondiente $\mathrm{R}$ vuelve a describir la conducta del asno (una solución intermedia se halla en I.BG "Satis me teneo, dum tuam ruditatem calcibus non moneo"). Poclria compararse también R "Terrore ... tacuit" con GI 10 "fit timor", si timor ha de atribuirse al asno.

Al v. 12, que acabamos de citar, donde el sujeto era viscera, pueden agregarse otros que se distinguen de $\mathrm{R}$ (cuando hay correspondencia) por asignar la función de sujeto al nombre de ser inanimado o abstracto en presencia de un referente animarlo o personal. Compárese 25-26 "te nulla potestas / in miseros armet" con RVg. "Ne quis in potestate sua velit aliquos terrere" o 2 "Ista quidem vestit aureus arma nitor" (con el referente personal sobreentendido) con RVg. "ornatus freno ex auro et argento ...", donde el propio Neckam, cuyas veleidades literarias también señalamos, suena: 8 "ornamenta nitent quam preciosa michi". La diferencia entre GI en 3-4 "vicus premit arctus asellum, / vexat onus, tardat natus eunclo labor" y el pasaje corres- 
pondiente de $\mathrm{R}$ constituido por participios (aparte de "in angusto"); v. q. Neckam "Pressus fasce, via miserandus asellus in arcta...". GI 15 "huic acuit tergum macies" frente a R "macer effectus est" representa un alejamiento de la lengua vernácula propia del autor, tanto en la construcción como en el léxico.

E. De la misma familia léxica se dan 2 arma, 20 armare, 2 nitor var., 17 nitens, 19 superbia, 1 superbire, 23 vivere (bis), 24 vita, 9 instare, 21 stare, que se agregan a la repetición de 3,14 premere.

La relación entre las partes del discurso da ventaja al sustantivo, según veremos al comparar GI con $\mathrm{R}$, excepto por 1 superbire.

En la formación de las palabras notamos 11 sessor, var. (ya en Séneca; v. q. R LXXIV, 12), y aparte de los compuestos que se apartan de la forma simple en cuanto al sentido, como el ya citado 9 instare, y 10 praeterire, otro con pref. asemántico, 5 inclamare. 16 In $(h)$ ers respecto a ars, representa uno de tantos compuestos con in- privativo, frecuentes en GI (aqui 'holgazán'). El diminutivo 3,5 asellus era corriente en las fábulas, como forma intercambiable con asinus (cf. Varrón, De rer., Isid.).

Por lo que veremos luego, en JR destacamos la forma simple 22 placere; $\mathrm{y}$, como antecedente de la frase sustantiva verbal romance 19 dare risum; por contraste, 7 dare veniam.

Por su extensión semántica se destaca 3 vicus 'barrio', luego 'calle bordeada de casas', 'calle', 21 aetas aqui por 'juventud' (cl.). 2 Arma está por arma equestria; asi lo comprendió LBG "Equus iuvenis et fortis, bene faleratus argenteo freno et sella deaurata et aliis ornamentis quibus equi ornari solent".

Volveremos sobre el léxico al comparar GI con R; adelantamos aqui que 10 timor puede interpretarse también como 'ocasión de temor'.

Se emplean en sentido figurado 1 vestire con nitor (o decor) como sujeto (con antecedentes literarios clásicos); 25 pennatus, dicho de bonum, nos hace pensar en el virgiliano E 9.463 "pennata fama” (v. q. i. F²).

15 Tergum es solidario tanto con nombres de personas como de animales (frente a dorsum, dicho de éstos). 13 Honestus y 17 nobilis, generalmente dichos de personas, se trasladan aquí a las cosas. Para aquél, cf. R, XV, 4 "honesta domus" 'casa rica', y piénsese en la solidaridad de cast. noble con nombres, p. ej., de ciudades.

Son afines 7 fastus y 20 superbia, 13 honestus y 17 nobilis; 9 instare y 19 manere (prescindiendo del uso sintáctico): se contraponen 19 manere et ib. fugere.

GI se diferencia de $\mathrm{R}$ y sus reelaboraciones (excepto Neckam) por formas menos allegadas al romance, como son los adjs. 3 ar(c)tus en corres- 
pondencia con angustus de todos los R, y 2 aureus donde las fábulas en prosa tienen "ex auro et argento" (pero RVg. " "argenteo et... ex auro" y LBG "argenteo ... et ... deaurata"). De todos los textos aludidos, incluyendo el de Neckam, se aparta por el virgiliano 5 sonipes (cf. En., 4.135, $11.600,638$ ), que también usara Fedro (cf. IV, 4.3 "Sonipes iratus"), y, según vimos, por el tecnicismo 1.14 falerae (que volveremos a encontrar en LBG como faleratus).

F [1]. Puede que no sea accidental la asonancia [nk] en 16 "Hunc videt, inque iocos audet Asellus inhers" (la conjunción, sin embargo, desaparece en algunos textos), ya que se alinea con otros muchos versos donde la asonancia $y / o$ la aliteración constituyen un recurso tan evidente como poco acorde con los modelos clásicos como 12 "commodat et mentem, menteque mensa minor".

[2]. Se combina con otras figuras; aquí con el poliptoton en el tantas veces citado 11-12 "dum vincere temptat / vincitur", y con el paralelismo, como parte de la retorización de gusto medieval del texto; véanse los vv. 1819 , sin antecedente en $\mathrm{R}$ 14-15 "Hunc premit ... / huic acuit..." se suma a los ejemplos menos felices de aliteración (v. s. 1).

[3]. Menudea la hipálage: 2 aureus es dicho de nitor y no de ib. arma (cf. 17 "sella nitens"; 14 assiduus, de iugum (por "assidue premere"); 25 "pennatis ne crede bonis", si pennatus se refiere a la Fortuna, por relación con $\mathrm{R}$, según vimos; pero también podría haber aquí una metáfora por reminiscencia bíblica; cf. Prov. 23:5 "Ne erigas oculos tuos ad opes ..., quia facient sibi pennas quasi aquilae, et volabunt in coelum”.

[4]. La característica más destacada, como fruto del propósito de GI de imitar a los clásicos, es el hipérbaton, tanto el que separa el nombre del elemento que lo modifica como el otro, más determinante en poesía, donde entre los elementos separados interviene el verbo (cf. 2 "vestit aureus arma nitor", 3 "vicus premit artus", 4 "natus eundo labor", 8 "cui via danda fuit libera”, etc.). El hipérbaton se combina con otras figuras, como la de la repetición y el quiasmo: 13 "privatur faleris, freno privatur honesto". Para el quiasmo, véanse también el v. 1 y el 15 , ya citado, y para la repetición paralelística, particularmente la del 17 ¿ubi sunt? (Neckam, según se vio, se limitaba al enunciado simple de la pregunta), y de las otras preguntas que empiezan con cur, vv. 18-19, que a su vez entrañan contraposiciones.

G. La manera de traducir, al no darse aqui tampoco, queda reemplazada por la trasposición que hemos visto de prosa a verso. 
H. En la manera de narrar afloran en GI caracteristicas que reconocemos como propias de $\mathrm{R}$, con la repetición seguida del personaje, ya en dos proposiciones distintas: 3 "Obstat asellus equo; vicus premit arctus asellum", o en la misma, esta vez en la variante: 11 "Sessor equi declinat equo".

Una peculiaridad suya es la introducción del segundo actante en el v. 3 sin relación sintáctica con el primero, como por un segundo exordio.

También se destaca el sesgo de la narración en cuanto a la polaridad: en GI el caballo es "deprivado" de sus guarniciones nobles (v. 13), en R "adquiere" las guarniciones rústicas, con una correspondencia de polaridad negativa a la positiva que ya obra en el interior de la transmisión de GI cuando 12 "cursum viscera rupta negant" se transforma en la lección que hemos adoptado, L "cursu viscera rupta patent".

III 1.1. Para comparar el texto ruiciano con la fábula latina del caballo $y$ el asno en cualquiera de sus versiones habremos de aislar primero la parte que se presenta como un cuento entretejido, según se ve sacándolo del contexto; a saber:

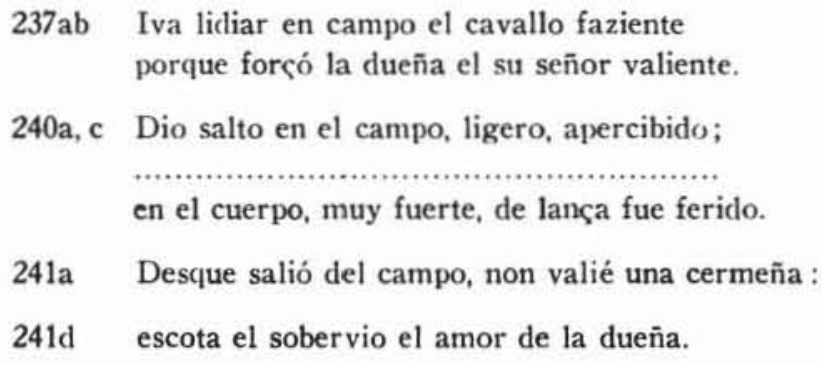

1.2. $\mathrm{Al}$ excluir GI y $\mathrm{R}$ de entre las fuentes directas de estos versos se plantea la posibilidad de que en otra colección, accesible a JR, se leyese la fábula que Rodriguez Adrados aduce como H 272 (v. s. 1.2), que trata de un caballo de guerra que muere en el combate.

De conocerla el Arcipreste, la suya sería una conflación de dos fábulas latinas, con la previa contaminación entre el combate y la "carrera" de otra fábula fedriana (v. s. ib.).

A favor de que JR entretejiera la fábula $\mathrm{H} 272$, verticla al latín en una colección hasta hoy desconocida, y la nuestra, obra la colocación del tema del combate en la primera parte, desde el propio exordio, y el relieve que se da desde un principio a la relación entre el caballo y el amo.

Por otras fábulas, como la del "gallo que falló çafir golpado", sabemos, sin embargo, que el Arcipreste podía trastocar el orden de los elementos por cuanto obraba desde un conocimiento de la fábula en su conjunto. La estrecha relación de caballo y caballero, por otra parte, echa sus raices en el 
concepto unitario de toda la naturaleza animada, y en la conocida armonía entre el caballo y el amo (v. q. i. 3.3).

1.3. Por esto y por la proverbial lujuria de la raza equina, la representación del caballo y caballero se prestaba para la increpación al amor, y, por añadidura, para ese propósito anticaballeresco en son de parodia que una y otra vez aflora en el Libro.

Para la probable dependencia de JR de los modelos acostumbrados y no de una versión latina de $\mathrm{H} 272$ obran las sugerencias que le brindaba el propio GI, con 2 arma (equestria), que podía entenderse como 'armas defensivas', vincere 'obtener el primer puesto en la carrera', que valía también 'vencer' a secas, y 12 viscera patere, que podía ser el resultado tanto del ib. cursus como de un combate. $\mathrm{Si}$, como suponemos, 11 sessor se leía en el modelo, 10 "fit timor" podía referirse a la refriega, tras de la cual el jinete se desentendería (11 "declinat") del caballo.

Recordaremos de paso que también en Isopet de Lyon había al principio un personaje ajeno a la fábula animalesca, allí un "valat" o campesino, que se paseaba monte arriba con su caballeria.

2.1. A modo de comentario de esta parte de la fábula ruiciana, bien sea ella fruto de conflación, o como nos parece más probable, interpolación por ampliación del original, valga el hecho de que el caballo venía relacionado tradicionalmente con la guerra; recuérdese a Virg., E 3.540 "bello armantur equi, bellum haec armenta minantur", y especialmente 4.134-135 "ostroque insignis et auro / stat sonipes ac fraena ferox spumantia mandit", donde se ensalza además el resplandor de sus guarniciones. Recuérdese a Isidoro en sus Etimologias, 12.1.43

Vivacitas equorum multa : exultant enim in campis; odorantur bellum; excitantur sono tubae ad proelium; voce accensi ad cursum provocantur; dolent cum victi fuerint; exultant cum vicerint ${ }^{51}$.

De este célebre paso se hacen eco muchos autores medievales; entre ellos Brunetto Latini, que en su Tesoro escribe del caballo (citamos de la versión anónima castellana):

"e vienta la batalla e alégrase e esfuérçase con el son de las trompas, e alégrase quándo vence e entristeze quando pierde (su señor), e bien se pueden apercebir quando lidian, en el continente de sus cavallos si vencerán o si deven ser vencidos" $\mathbf{6 2}$.

51 Cf. ed. W. M. Lindsay, Oxford, 1911.

52 En la traducción entresacada por S. Baldwin, The Medieval Castilian Bestiary, Exeter Univ., 1982, pág. 49. 
El pasaje isiduriano interesa asimismo por la contraposición 290b vencer / ser vencido, que JR traslada de GI, pero que cuadra también al cuento intercalado. Tan frecuente es en las letras medievales que constituye un topos, y se traslada también a otros ámbitos que no son los de la guerra (de la mujer escribirá, p. ej., el autor del Libro de miseria de omne: 114b "ella quier siempre vencer e nunca quier ser vencida).

2.2. El salir del campo (241a), por otra parte, se acompañaba con la infamia de la derrota; así en el Poema de Fernán González, 44a-c:

Todo aquel de vosotros que del campo saliere

quede por alevoso que tal fecho fiziere,

lo que pudo contribuir a hacer del amo del caballo ruiciano un "caballero" alevoso.

3.1. También pertenece al trasfondo común, y podía recrecérsele al texto ruiciano aun independientemente del modelo, el significado alegórico del caballo, símbolo de la soberbia (y de cada una de sus guarniciones), que conocemos, por la tradición iconográfica y por los padres y doctores de la Iglesia, entre otros por San Bernardo ${ }^{53}$, y que se prestaría para esa lectura en el plano de la "moralidad" que JR, entre serio y jocoso, tan a menudo reconienda.

3.2. También percibimos ecos textuales bíblicos, a través de un saber difuso. Así la idea de la muerte temprana que se prospecta al impío en la estr. que precede inmediatamente a la fábula, nos recuerda un concepto corriente en el A. T., y muy fundamental en los libros sapienciales, donde se promete la longevidad como premio de la virtud (cf. Prov. $3: 2,9.1$ ). En nuestro texto podría relacionarse también con la de la fugacidad de los bienes de fortuna, entre los cuales se cuenta la vida (R y GI), o con una reminiscencia $e$ contrario de GI 23 "vive diu, sed vive miser".

3.3. Al otro extremo, pero sin una distinción neta, está el acervo popular de los refranes, que al mismo tiempo nos permiten apreciar la divulgación de los temas, como el de la decadencia: "Caballo de regalo suele parar en rocín molinero". "Ni a caballo corredor ni a hombre rifador le duró nu-

53 Cf. E. Kirschbaum ct al, Lexikon der christlichen Ikonographie, Roma-Freiburg, 1968-76, s. v. Pferd, y J. Leclercq, Recucil d'Etudes sur Saint Bernard et ses écrits. Roma, Ed. Storia e Letteratura, 1969, 2, pág. 151 y sigs., con cuadros muy puntuales (aunque las referencias no sean siempre exactas). 
cho el honor" y la relación entre el cabalgar y la ira (y por ende la soberbia): "No hay hombre cuerdo a caballo", y con sentido similar, con referencia específica a la pelea, " $\mathrm{Ni}$ a caballo corredor ni a hombre rifador le duró mucho el honor".

Para las circunstancias especificas de la fábula, véanse especialmente " $\mathrm{Ca}$ ballo que alcanza, pasar quiere", "A caballo bravo carrera larga" (que sólo puede entenderse hoy pensando en el sentido antiguo de largo).

No hará falta recordar, además, la frecuencia con que mujer, espada o lanza aparecen juntos en muchos refranes. El propio JR se refiere a uno concerniente a la pasión amorosa : 565ab "Piensa si consintrá tu cavallo tal freno, / que tu entendera amasse a Frey Moreno", que al mismo tiempo ilustra esa simbiosis entre el hombre y el animal ("Yo y mi caballo tenemos un cuidado") ${ }^{54}$, que en la comparación con los textos latinos nos parecía propia de JR.

3.4. En una dimensión apologética fuertemente persuasiva y estilizada a lo popular, con el acento puesto en el actante humano, parte de nuestra fábula puede compararse con un pasaje que en el Arcipreste de Talavera (cap. 30) suena:

Pues, dime agora, que Dios te vala, ¿viste jamás ombre enamorado que non fuese elato, sobervio, e argulloso, e aun tal que non es menester que ninguno le fahle contra su voluntad, e casi a los otros tiene en menos precio, que le paresce que todos nada, fijos de nada, si non él? ¿... que non ay cosa que de delante se le tenga? Cuando toma su cavallo, si es de tal estado, cuando fuere por la calle, non guardará asnos nin burros, pobre nin mal vestidos, que con todos non tope muy descortésmente sin manzilla nin duelo, con la fantasía e orgullo que en el celebro lieva de su dama .... albarcando toda la calle, con su cavallo trotón, faca, mula, de través brocando e de espuelas firiendo, e con sus piernas e pies a cuantos falla encontrando e derrocando, con su gritillo: "¿Iha! ¡Biva la linda enamorada mía!”

4. Más allá de las tradiciones verbales está la vida diaria, especialmente la rural. Por lo que pudo haber poligénesis respecto a la otra fábula de $\mathrm{Fe}$ dro (v. s. II 1.1.1), por cuanto la 241c acenia, que mutatis mutandis podría remitir a pistrinum, se nombra dentro de una serie de quehaceres campestres comunes a todo el Mediterráneo ${ }^{86}$.

54 Cf. L. Martínez Kleiser, Refranero general ideológico español, Madrid, RAE, 1953 ; cf. los n. ${ }^{\text {он }} 8.145,8.256,21.782,8.264,19.565$ y 8.137 .

ss A. Martinez de Toledo, El Arcipreste de Talavera o sea El Corbacho, ed. L. B. Simpson, Berkeley, 1939, págs. 90-1.

58 Entre los muchos hitos de continuidad valga el tenor del art. asno en el Tesoro de la Lengua castellana de S. de Covarrubias. 
IV 1. Para la comparación de JR con sus modelos inmediatos en cuanto al contenido, agregaremos algunos datos a los que ya indicaba Lecoy (v. s. II A).

Aunque el sujeto no vaya al principio (nos hallamos aqui en la parte amplificada), JR se aproxima más a $\mathrm{RVg}$. en el movimiento de la narración, y también en el arranque de la reacción del corcel: 6 "Satis me teneo", como expresión de sabor coloquial, pero en correspondencia con la figura de la aposiopesis, según vimos (v. s. II 3.2.1, F), pudo dar pie a la actuación del caballo con el "derribo" del asno, que no tiene antecedente explícito en los modelos que conocemos.

$\mathrm{La}$ indicación en $\mathrm{R}$ de la distancia de la que procedia el burro, "de longe" (o "de luengas tierras" para emplear las palabras de Isopet), pudo pasar a $237 \mathrm{~d}$ mucho, en la interpretación más obvia del verso (v. s. I D 6). "Ille, in prato pascens" (v. q. RV, RF, RVg.), traslados a la primera parte del cuento, podría explicar 239c "en medio de la varga" (v. s. I E 3.2.1.1) como "en medio del llano" (para expresarnos con las palabras del Poema de Fernán González 694b). 244a Dorado, que nos llamaba la atención en 0.2.9, y que en I E 3.2 explicábamos como 'de oro' o íd., tiene un antecedente en los $\mathrm{R}$, que en lugar de"nacco" ponen "sella ex auro et argento" o "sella deaurata" (v. s. II 3.1.1).

Para el movimiento de $237 \mathrm{~d}$ ir delante del asno respecto al caballo, sólo nos consta el paralelo de Isopet, I, 4 "Un asne devant lui alloit", como manifestación de una fuente común o innovación paralela. Sobre otras características de la narración en JR volveremos en el último apartado.

2. Si luego pasamos al parangón verbal, hemos de volver sobre algunos de los mismos apartados de I y III.

B. La distancia que media entre GI y $\mathrm{R}$, debida en primer lugar al metro, se transmite a JR compatiblemente con la diferencia entre métrica cuantitativa y acentual. No entramos en el problema del empalme entre los dos tipos de versos. Sólo reparamos de un modo empírico en la comparación entre el alejandrino, con pausa final constante y cesura más o menos fuerte entre los dos hemistiquios y la unidad que constituye el dístico, pero que aquí se realiza sólo en 11-12, 23-24 y 25-26: con lo que queda una alta proporción de versos con pausa final, algunos comparables con los de JR, como 1, 3, $11,15,18-19$ por la pausa mediana, y otros menos por su hechura unitaria, como 2,14, 20, que ilustran el carácter asimétrico propio de la poesía latina. como $4,8,10,13,16$. Por la pausa más leve al final del v. $244 \mathrm{c}$ los dos últimos vv. de esta cuarteta son los que más se pueden yuxtaponer al latín, aqui con 21-22. Pueden compararse, pues, el hemistiquio 238d "e no 1 fue 
bueno" con parte del hexámetro o pentámetro; cf. 22 "plus tamen ista placent", aunque los contextos sean distintos; un alejandrino está por un v. latino: 242a "Tenié con el grand yugo essolladas las cervizes" y 14 "hunc premit assiduo reda cruenta iugo", v. q. $244 \mathrm{~d} \leftarrow 20$; dos alejandrinos por un v. latino: $243 \mathrm{ab} \leftarrow 15$. La agrupación dentro de la cuarteta de $3 \mathrm{vv}$. + 1 en 236, 237, 238 y 241 predetermina una disposición distinta a la de los disticos.

D [7]. En la morfosintaxis la ausencia de preposición en $244 d$ "Vengue la tu sobervia tanta mala postilla", yuxtapuesto a "Vindicat elatos iusta ruina gradus", hace que nos percatemos de la cercanía entre el castellano y el latín en el ámbito de las abstracciones doctrinales (cf. Virg., E, 4.13, "Demuestra el miedo el ánimo sin lustre" en la traducción de A. López Pinciano ${ }^{57}$ ), con una exigencia mayor de raciocinio en la interpretación.

[10.1]. En las dos primeras cuartetas, las oraciones compuestas del cuento intercalado, 237bc, 238a-c, pueden compararse con las de RVg. (4-5); los vv. restantes, en cambio, moldeados en GI muestran un predominio parecido de la oración simple, y mayor si comparamos 240 b "coidó ser vencedor e fincó el vencido" con 11-12 “dum ...”. La parátaxis constituye la semejanza más llamativa, y al parecer buscada, entre JR y su modelo literario, subrayada incluso por la enclisis del pron. : 243 c "Víclolo" $\leftarrow 16$ "Hunc videt".

Las construcciones del tipo 243ab "los quadriles salidos ..." tienen un paralelo en otras fábulas de GI, donde éste emplea y hasta abusa del ablativo absoluto (cf. 8.1 "osse retento", 3 “osse revulso"); por lo que no dudaríamos en designar 237c "lorigas bien levadas" como parte del ornato latinizante de la sintaxis de JR, que por el participio recuerda ITes. 5:8 "induti loricam (fidei)" o Ef. 6:14 "succincti loricam (iustitiae)" (¿ traslados al estilo seudoépico?).

[10.2]. Otro rasgo común, que creemos ser fruto de imitación (habrá que comparar las fábulas gualterianas con las otras y con otras partes del Libro) es el asíndeton; compárese $237 \mathrm{c}$ con 2 , d con $3,238 \mathrm{~d}$ con $4,239 \mathrm{~cd}$ con $5-6,240 \mathrm{bc}$ con 11-12; y, para un caso de oración asindética frente a otra unida por conj. cop., c 243c con 16.

En cambio, la unión del discurso directo sin verbum dicendi en GI 17 es inaccesible para el estilo narrativo vernáculo, que lo introduce aunque sea un simple 243d Diz (en el texto latino 17 "Dic" exhorta a contestar a una interrogación retórica cuya contestación se da por descontada).

57 Philosophia antigua poética, ed. A. Carballo Picazo, Madrid, 1969, reimpr. 197. 1. pág. 165 . 
[11]. El orden de las palabras del Libro es a GI como el castellano al latino: 245d "Non pueden durar siempre" $\leftarrow 21$ "Stare diu non sufficit". El orden es idéntico en la interrogación en 243d, 244ab “¿Dó (es) ...?” $\leftarrow$ $17 u b i$...? y en la exhortación, según acabamos de ver en $244 \mathrm{~d} \leftarrow 20$ (aparte del hipérbaton).

Coinciden los dos textos en la anticipación del complemento instrumental en 238a "Con los pies e las manos en con el noble freno..." $\leftarrow 1$ "freno sellaque superbit”. El énfasis ocasiona la inversión: 239b "al caballo embarga" $\leftarrow 3$ "Obstat ... equo".

[12]. La tradición vernácula contaba con suficiente experiencia como para barajar entre sí los conceptos abstractos de $244 d \leftarrow 20$, pero no para adecuarse a 2 "ista quidem vestit arma nitor". Tampoco podía reflejar fácilmente la distribución distinta de las funciones, como en 3-4 "Vicus premit a(c)tus asellum ... tardat ... labor", o 15 "Huic acuit tergum macies ...", en cuyo lugar tenemos aquí 239ab "Estava refusando el asno con la carga / andava mal y poco", y 242a-243b "Tenía (el caballo) ... / ... / el espinazo agudo ...".

[13]. De entre estos tramos, 239b "andava mal y poco" 'no andaba casi' o 'nada' $\leftarrow 4$ "tardat ... labor" interesa también por la relación en este caso de negativo a positivo en cuanto a la expresión verbal.

[14]. La comparación que vimos en I D no tiene antecedente en los textos latinos, como no sea en la metáfora GI 21 "pennatis ... bonis".

E 0. Interpolando un apartado que no tiene correspondencia con los de arriba, empezaremos observando que en el breve espacio de 40 vv. castellanos y 26 latinos hemos observado un alto número de correspondencias léxicas, de las cuales algunas son obligadas o de repertorio, por pertenecer al contenido esencial de la fábula, común a JR, GI y R, como son $238 \mathrm{a}$, 244a freno $\leftarrow 1$, 17 frenus, 244 a silla $\leftarrow 1,17$ sella, $238 \mathrm{~d}$ miedo $\leftarrow 9$ timor ( $\mathrm{R}$ terror), además de los nombres (comunes) de los animales protagonistas.

La mayor cercanía de JR a GI arroja todavía más palabras, en la parte didáctica, o sea en el discurso del asno y en la moraleja: $244 \mathrm{~b}$ sobervia $\leftarrow$ 19 superbia, 245c fuerça $\leftarrow 21$ vis, 245 c edad $\leftarrow 21$ aetas, y con típica adaptación vernácula, ib. c onra $\leftarrow$ ib. honor (v. q. 1.442a "falsa onra" $\leftarrow$ "falsus honor"); con aproximación, $245 \mathrm{~d}$ siempre $\leftarrow 23$ diu, además de $244 \mathrm{~d}$ vengar $\leftarrow 20$ vindicare; en la parte narrativa: 244 a noble $\leftarrow 17$ nobilis, $243 \mathrm{~d}$ dezir $\leftarrow 17$ dicere, $240 \mathrm{~b}$ vencer $\leftarrow 12$ vinccre (pero con aplicación distinta; $\mathrm{v}$. $\mathrm{s}$. III 1.3 ), $243 \mathrm{c}$ ver $\leftarrow 16$ videre, $24.3 \mathrm{~d}, 244 \mathrm{ab}$ do $\leftarrow 17$ ubi (?), con cambio de 
categoria gramatical: $236 \mathrm{~d}$ armado $\leftarrow 2$ arma ; de tema distinto: 240d entrañas $\leftarrow 12$ viscera, 243b espinazo $\leftarrow 15$ tergum, 243a ijada $\leftarrow 15$ armus, $243 \mathrm{~d}$ compañón $\leftarrow 17$ sodes (v. q. 23 socius); $244 \mathrm{a}$ dorado $\leftarrow 2$ aureus, $239 \mathrm{~b}$ andar $\leftarrow 4$ ire, 239d dezir $\leftarrow 5$ inclamare, 239b embargar $\leftarrow 3$ obstare, $238 \mathrm{~d}$ quedar $\leftarrow 9$ instare: 243 c reir $\sim 16$ iocus (Ad irridere) aparecen en contextos distintos. Volveremos más abajo sobre $242 \mathrm{a}$ yugo $\leftarrow 14$ iugum por la diferencia de sentido. 240 Dar salto sin antecedente en el original, hubiese podido tenerlo en facere saltum (cf. HSz, $25 \mathrm{Ab}, \mathrm{y}$ Thiele, LXXIX, 15). Por otra parte, 20 placere de traclucirse hubiese dado $1408 \mathrm{~b} f(a z)$ er plazer, y ocasionalmente $1440 \mathrm{~b}$ plazer.

La repetición de $244 \mathrm{bd}$ sobervia aúna GI 19 superbia y 1 superbire; la repetición de $237 \mathrm{bc}$ valiente no tiene antecedente en los modelos. Aparece una voz cast. por dos latinas en 237a, 238b, 239bc cavallo por 5 sonipes y 1 , 3, 11 equus (a diferencia de otras fábulas donde JR multiplica los nombres; cf. 1437a marfusa, 1441c gulpeja, 1446d gulfara $\leftarrow 1,2,7$ vulpes).

[1.2]. En cuanto a la distribución de las categorias gramaticales, llama la atención la abundancia de adjetivos, no tanto de los predicativos, como valiente, sino de los atributivos: 244 a dorado $\leftarrow$ GI 2 aureus devuelve a esta categoría lo que en $\mathrm{RVg}$. era un sintagma: $238 \mathrm{~b}$ soberbio y $243 \mathrm{~b}$ agudo resultan de la redistribución a su respectiva clase de 1 superbire (pero véase también 20 clatus) y 15 acuere, cuyo correspondiente francés se halla en el Isopet dc Lyon, v. 41 "Magrace le dos li aguise".

[2]. El inaccesible 5 sonipes produce una perifrasis con 238a pies y b sueno; con 14 assiduus se corresponde en el contexto 242a grand, pero por el sentido, 241c a vezes... a vezes.

[3]. La gama de posibles asociaciones nos hace dudar entre 1 superbire y gaudere para $237 \mathrm{c}$ sentirse muy valiente, inclinándonos hacia el ámbito psíquico, aunque 18 macies nos colocaria por contraposición en el ámbito de la salud.

243d Empellada tiene en común con 20 elatus gradus pl. también el implicar movimiento ; cf. 239d.

Tendiendo un puente entre el vocabulario y el contenido podriamos afirmar que 244b renzilla, si tiene un antecedente en 5 inclamare, se relaciona con los regaños cuales aparecen en la parte no traducida de (iI (vv. 6-8), que no es exclusiva de éste, según vinos.

242a Essollado (dicho de la cerviz) aúna la acción de 14 premere como causa e ib. crucntus (dicho por hipálage de la rueda del carro) como efecto: 239 a refusar podría anticipar 10 "surda preterit aure", en el sentido de 'ha- 
cerse el sordo', y por tanto, 'negarse a obedecer'; $245 \mathrm{c}$ salud e ib. valentia, cono términos afines, se suman en la correspondencia con 22 forma.

F [1]. La repetición de fonemas es más evidente e insistente en el texto vernáculo, con rimas $\mathrm{y}$ asonancias internas $\mathrm{y}$ otras asociaciones acústicas : 237bc "muy valiente se siente", 237d "delante ... doliente", 240c "fuerte ... fue ferido", 242b “a vezes ... narizes", 242d "pies de perdizes”, 243a "salidos, somidas" ; con repetición de vocales: $243 \mathrm{~d}$ "conpañero, sobervio, ¿ dó son ...", y combinación de las mismas: 243a "quadriles ... ijadas", extremando así un recurso característico de GI (aunque en esta fábula no tanto como en otras).

La figura etimológica, tantas veces citada, del v. $240 \mathrm{~b} \leftarrow 11-12$ ocupa un lugar preeminente (también el otro v. que ya hemos aducido, $1.428 \mathrm{c}$ "el vencedor ha onra del precio del vencido", revela la misma apertura hacia los valores retóricos más evidentes del modelo: cf. alli 18.11-12 "victor / tantus erit, victi quanta gloria fuit").

[2]. Coincide JR con GI en el paralelismo del ubi sunt?, llevado más allá en el texto romance (cf. 243a-244ab respecto a 17, 18-19), pero con anticipación y transformación de las preguntas retóricas del v. 18, con consecuencias muy positivas para el fluir rectilíneo del discurso hacia la moraleja.

Reaparece $\sin$ correspondencia de verso a verso, la anáfora: $241 \mathrm{c}$ "a vezes a la noria, a vezes a la acenia"; véase 13 "Privatur faleris, auro privatur honesto", y el quiasmo: 242bc "finchadas las narizes, / rodillas dessolladas"; véase "gaudet equus faleris, freno sellaque superbit".

Difieren, en cambio, JR y GI en cuanto al desdoblamiento y a la disposición de miembros crecientes, que hemos visto en el texto castellano. El hipérbaton, en cambio, es propio de GI; a no ser que se considere tal "mucho delante'l iva el asno maldoliente", interpretando mucho como modificación de maldoliente, pero sin que pueda considerarse como ornato retórico; v. s. II D 10.

[3]. En la acumulación, 245c "que fuerça e edad e onra, salud e valentía”, el polisíncleton recuerda la repetición de la conjunción negativa en 21 "nec vis, nec honor, nec forma, nec etas" (por lo que ha cle conservarse a pesar de la noble sinalefa que repugnaba a Corominas), también en cuanto hace de contrapeso a los muchos casos de asincleton que hemos visto en D) 10.2 .

V. A JR le hemos seguido la pista en las equivalencias/diferencias sintácticas y léxicas, salvando en lo posible la dificultad que ya señalamos de 
distinguir entre opciones y soluciones obligadas. Dichas equivalencias y diferencias revierten en su labor de traductor-narrador sin que se pueda trazar una línea neta entre los dos aspectos.

1. Para la del intérprete incluimos los traslados de un punto de la fábula a otro: asi, en el caso de 238a noble respecto a 17 nobilis, 243a dorado respecto a 2 aureus, $243 \mathrm{~d}$ compañón respecto a 23 socius, y también posiblemente 242b inojar y c fazer muchas prizes respecto a 9 supplicare.

En cuanto a los distintos grados de cercania al modelo, la versión abarca varias gamas, que van desde el préstamo, 254c edad $\leftarrow 21$ actas 'juventud' (seguido, sin embargo, de la glosa, d mancebia) a las versiones libres, pasando por cierto número de traducciones serviles por palabras homólogas, pero de sentido distinto, 242a yugo por 14 iugum 'lanza de carro', o de palabras homólogas con matices o asociaciones diferentes, como en el caso de $240 \mathrm{~b}$ vencer pas., vencedor $\leftarrow 11$ vincere (tras la interpretación de 2 arma en el ámbito del combate).

La asociación de ideas puede comprender por contraste el paso de 3 "vicus ... artus" a 239c "en medio de la varga". A veces JR conserva sólo un componente del semantema latino: el del tiempo en $244 \mathrm{c}$ siempre respecto a 14 assiduus; tal vez el del espacio (y movimiento) en $243 \mathrm{~d}$ empellada pl. $\leftarrow$ 19 fugere (aunque aquél se diga de un ser animado y del resultado de su movimiento impulsivo, y éste (le un concepto abstracto); el de la cuantificación, que aparece explícita en $243 \mathrm{c}$ "bien tres vegadas", implícita y relativa en 16 auderc.

Por otra parte, como los demás traductores de la época, y llevado por la necesidad de desentrañar el significado de las palabras latinas, amén de adaptarse al metro y estilo de la cuaderna via, JR desdobla: 245 c "salud e valentía" $\leftarrow 21$ forma, o modifica: 244 c mesquino e con mucha manzilla, inspirado, según vimos, en 19 gemitus; $245 \mathrm{~b}$ soberbio con su grand orgullia, si lo podemos relacionar con 20 elatus.

En 241a arar + traer la leña, respecto a 15 labor, representa el desdoblamiento visualizador, además de la comprensión del término latino en sentido restrictivo.

Junto con la elección de palabras de uso y/o significado más genérico, como $239 \mathrm{~d}$ dezir $\leftarrow$ inclamare o $254 \mathrm{~d}$ poder en correspondencia con 22 sufficere, hemos visto expresiones más visualizables como 238ab "con los pies e con las manos... / fazia tan gran sueno" respecto a 5 sonipes: véanse también 239d "buscad carrera larga" $\leftarrow 10$ minac, 240cl salirsele a uno las entrañas $\leftarrow 12$ viscera rumpi y el ya citado $242 \mathrm{~b}$ inojar respecto a 9 supplicare; por lo "vivencial" de la interpretación, 20 "iusta ruina" respecto a 244b "mala postilla" (modificado por el ponderativo tanto); y traducciones 
centradas en el sujeto personal, como en $239 \mathrm{~b}$ "andar mal e poco" $\leftarrow 3$ premere (vicus) y 4 tardare.

2. La visualización que acabamos de constatar pertenece también a JR narrador, un aspecto en el que nos hemos detenido en la presentación de la fábula.

La investigación de las "fuentes" y la comparación con los modelos nos presenta ahora el problema de si en la taracea de los elementos constitutivos han de reconocerse dos fábulas esópicas, lo que constituiria un caso único en el Libro (aparte las fábulas de 82-87 y 321-375, en que la fábula esópica viene contaminada o muy reelaborada), o si el cuento intercalado es una amplificación, como nos inclinamos a pensar.

En todo caso interesa el ensamblaje: reconocemos ahora que el primer exordio $237 \mathrm{a}-\mathrm{c}$, en que aparece el corcel de lidia encaminado hacia el combate, pertenece al cuento intercalado. El segundo exordio (239a), con el verso que sigue, presenta al otro protagonista y el primer encuentro de los dos, con la imitación directa del texto de GI. El doble exordio, no obstante, tiene un antecedente formal en los vv. 1 y 3 de éste.

En la fábula ruiciana el encuentro entre los dos protagonistas aboca no sólo a la interpelación, sino a la acción, con el derribo del burro, y consiguiente despedida (239bc). La derrota del caballo (en son de duelo) y sus secuelas (con la vuelta a los modelos latinos) quedan separadas del segundo encuentro por la conclusión del cuento caballeresco intercalada en 241d.

En GI, la reacción verbal del caballo y la ponderación de su propia dignidad (6-8), y luego el hecho de ser privado éste de sus guarniciones, se prestaban para la trabazón del cuento, a la que JR en parte renuncia.

El discurso del burro (tras un 243c "Vidolo" $\leftarrow 16$ "hunc videt") representa en el texto ruiciano la retorización, que se destaca como característica principal clel texto gualteriano, y a la que JR se sustrae en parte cuando transforma las preguntas abstractas de 18-19 en una descripción del caballo derrotado, que, aun dentro del carácter retórico de la enumeratio, podría considerarse como una amplificación de RVg. 13 "onustus ibat per semitas".

Entre los elementos retóricos podría contarse también la amplificación de GI 5 sonipes, con la descripción de la exuberancia sonora del caballo que espanta a los demás jumentos o animales (238a-c).

Las amplificaciones, en cuanto van más allá de GI, restan aún más a ese movimiento rápido hacia el desenlace que debería caracterizar al cuento esópico. De ahí que los elementos de "vivacidad" que generalmente se alaban en JR, tienen también una vuelta de hoja negativa. Lo mismo diremos de la ironía (en GI 5 sonipes / 3 asellus), que estalla en las risotadas asnales del v. 243c, pero también se hace fácil y como "de manera" con el juicio de me- 
nos precio 241a "non valié una cermeña" y con la comparación muy trillada 242d "como pies de perdices".

Concluiremos diciendo que la cláusula $273 \mathrm{c}$ "lorigas bien levadas" nos ha permitido tender un puente entre el texto castellano del s. xiv y Fedro, a través de GI. Los eslabones intermedios son múltiples, y sólo en parte están identificados. Al asomarnos a un campo alejado de nuestros estudios ordinarios, hemos constatado cuánto está aún por hacer para una comprensión histórica más fehaciente del texto del Libro del Arcipreste en las partes donde el modelo o modelos complementan el testimonio de los manuscritos. 